\title{
Role of the Agrobacterium tumefaciens VirD2 Protein in T-DNA Transfer and Integration
}

\author{
Kirankumar S. Mysore, ${ }^{1,3}$ Burgund Bassuner, ${ }^{1}$ Xiao-bing Deng, ${ }^{1}$ Nune S. Darbinian, ${ }^{1}$ \\ Andrei Motchoulski, ${ }^{1}$ Walt Ream,${ }^{2}$ and Stanton B. Gelvin ${ }^{1,3}$ \\ ${ }^{1}$ Department of Biological Sciences, Purdue University, West Lafayette, IN 47907-1392, U.S.A.; \\ ${ }^{2}$ Department of Microbiology, Oregon State University, Corvallis 97331, U.S.A.; ${ }^{3}$ Purdue Genetics Pro- \\ gram, Purdue University, West Lafayette, IN 47907-1392, U.S.A. \\ Accepted 3 April 1998.
}

VirD2 is one of the key Agrobacterium tumefaciens proteins involved in T-DNA processing and transfer. In addition to its endonuclease domain, VirD2 contains a bipartite C-terminal nuclear localization sequence (NLS) and a conserved region called $\omega$ that is important for virulence. Previous results from our laboratory indicated that the $\mathrm{C}$ terminal, bipartite NLS and the $\omega$ region are not essential for nuclear uptake of T-DNA, and further suggested that the $\omega$ domain may be required for efficient integration of T-DNA into the plant genome. In this study, we took two approaches to investigate the importance of the $\omega$ domain in T-DNA integration. Using the first approach, we constructed a T-DNA binary vector containing a promoterless gus $A$-intron gene just inside the right T-DNA border. The expression of $\beta$-glucuronidase (GUS) activity in plant cells transformed by this T-DNA would indicate that the $T$ DNA integrated downstream of a plant promoter. Approximately $0.4 \%$ of the tobacco cell clusters infected by a wild-type $A$. tumefaciens strain harboring this vector stained blue with 5-bromo-4-chloro-3-indolyl $\beta$-Dglucuronic acid (X-gluc). However, using an $\omega$-mutant $A$. tumefaciens strain harboring the same binary vector, we did not detect any blue staining. Using the second approach, we directly demonstrated that more T-DNA is integrated into high-molecular-weight plant DNA after infection of Arabidopsis thaliana cells with a wild-type $A$. tumefaciens strain than with a strain containing a VirD2 $\omega$ deletion/substitution. Taken together, these data indicate that the VirD2 $\omega$ domain is important for efficient T-DNA integration. To determine whether the use of the T-DNA right border is altered in those few tumors generated by $A$. tumefaciens strains harboring the $\omega$ mutation, we analyzed DNA extracted from these tumors. Our data indicate that the right border was used to integrate the T-DNA in a similar manner regardless of whether the VirD2 protein encoded by the inciting $A$. tumefaciens was wild-type or contained an $\omega$ mutation. In addition, a mutant VirD2 protein lacking the $\omega$ domain was as least as active in cleaving a T-DNA border in vitro as was the wild-type protein. Finally, we investigated the role of various amino ac-

Corresponding author: Stanton B. Gelvin; Telephone: 765-494-4939; Fax: 765-496-1496; E-mail: gelvin@ bilbo.bio.purdue.edu ids of the $\omega$ and bipartite NLS domains in the targeting of a GUS-VirD2 fusion protein to the nucleus of electroporated tobacco protoplasts. Deletion of the $\omega$ domain, or mutation of the 10-amino-acid region between the two components of the bipartite NLS, had little effect upon the nuclear targeting of the GUS-VirD2 fusion protein. Mutation of both components of the NLS reduced, but did not eliminate, targeting of the fusion protein to the nucleus.

Agrobacterium tumefaciens is a soilborne phytopathogen that causes crown gall tumors in plants (for recent reviews, see Gelvin 1992; Hooykaas and Beijersbergen 1994; Zupan and Zambryski 1995, 1997; Sheng and Citovsky 1996). The process of tumor formation involves the transfer from the bacterium and integration into the plant genome of a specific segment of the $\mathrm{Ti}$ (tumor inducing) plasmid, the $\mathrm{T}$ (transferred) DNA (Chilton et al. 1977). T-DNA is flanked by 25-bp, imperfect, direct repeats called border sequences (Yadav et al. 1982; Slightom et al. 1985). Only the right border is required in cis for efficient T-DNA transfer (Wang et al. 1984; Peralta and Ream 1985; Jen and Chilton 1986). T-DNA encodes enzymes responsible for the biosynthesis of lowmolecular-weight compounds termed opines (Montoya et al. 1977) as well as for enzymes involved in the synthesis of auxins and cytokinins (Akiyoshi et al. 1983; Schroder et al. 1983). Expression of these latter genes in transformed cells causes tumorous proliferation of the plant tissue. Virulence (vir) genes necessary for T-DNA processing and transfer lie elsewhere on the Ti plasmid. vir gene expression is induced by phenolic compounds produced by wounded plants (Stachel et al. 1985). The vir region of octopine-type Ti-plasmids is composed of at least eight complementation groups that include virA, virB, virC, virD, virE, virF, virG, and $\operatorname{virH}$ (Sheng and Citovsky 1996).

T-DNA processing involves the nicking of the T-DNA borders between nucleotides 3 and 4 (Albright et al. 1987; Wang et al. 1987) by the VirD1/VirD2 endonuclease (Yanofsky et al. 1986; Jayaswal et al. 1987; Stachel et al. 1987). This process results in the generation of single-stranded TDNA molecules (T-strands) tightly associated with the VirD2 protein at the $5^{\prime}$ end (Herrera-Estrella et al. 1988; Ward and Barnes 1988; Young et al. 1988; Howard et al. 
1989). These single-stranded DNA molecules are transferred to the plant cytoplasm (Tinland et al. 1994; Yusibov et al. 1994). It has been proposed that the T-strand is transferred as a protein-nucleic acid complex (the T-complex; Howard and Citovsky 1990). In addition to T-DNA and VirD2, this T-complex would contain the single-stranded DNA binding protein VirE2 (Gietl et al. 1987; Christie et al. 1988; Citovsky et al. 1988; Das 1988) that is believed to protect the T-DNA from nucleolytic activity (Christie et al. 1989). Recent evidence, however, suggests that VirE2 protein and the VirD2/T-strand complex may exit the bacteria separately (Binns et al. 1995; Sundberg et al. 1996).

The T-DNA border-specific endonuclease activity lies entirely within the N-terminal 228 amino acids of VirD2. This region and two very short regions near the $\mathrm{C}$ terminus are the only highly conserved domains of this protein (Steck et al. 1990). However, a region important for virulence resides in the C-terminal half of the protein. Deletion and insertion mutations in this region do not affect T-DNA border cleavage (Yanofsky 1986; Jayaswal et al. 1987; Steck et al. 1990). Subsequent experiments indicated that VirD2 and VirE2 proteins contain nuclear localization sequences (NLS) that presumably serve to direct the complexed T-strand to the plant nucleus (Herrera-Estrella et al. 1990; Citovsky et al. 1992; Howard et al. 1992; Shurvinton et al. 1992; Tinland et al. 1992; Rossi et al. 1993; Citovsky et al. 1994). VirD2 protein contains two putative NLS regions: an Nterminal, monopartite NLS (Herrera-Estrella et al. 1990; Tinland et al. 1992) and a C-terminal, bipartite NLS, rich in basic amino acids, resembling that found in Xenopus laevis nucleoplasmin (Robbins et al. 1991; Tinland et al. 1992). Although the N-terminal NLS can target a reporter protein to the nucleus (Herrera-Estrella et al. 1990; Tinland et al. 1992), mutagenesis experiments suggested that only the Cterminal NLS contributes to the targeting of T-strands to the nucleus (Shurvinton et al. 1992; Koukolikova-Nicola et al. 1993; Rossi et al. 1993). However, precise deletion of this C-terminal NLS only slightly (by $40 \%$ ) reduced the virulence of A. tumefaciens (Shurvinton et al. 1992). The VirE2 single-stranded DNA binding protein, which contains two NLS (Citovsky et al. 1992), may therefore target T-DNA to host nuclei in the absence of the VirD2 NLS. Shurvinton et al. (1992) identified another region of VirD2, called $\omega$, that was very important for virulence. The $\omega$ region consists of the five highly conserved penultimate amino acids DGRGG. These amino acids are not part of a known NLS motif, but their deletion resulted in a decrease in virulence by almost two orders of magnitude (Shurvinton et al. 1992).

We recently obtained evidence that tobacco cells infected by $A$. tumefaciens strains lacking the C-terminal NLS and the $\omega$ sequences can accumulate relatively high levels of $\mathrm{T}$ DNA-encoded transcripts within $24 \mathrm{~h}$ after infection (Narasimhulu et al. 1996), despite the fact that a VirD2 $\omega$ deletion/substitution mutant strain is almost avirulent (Shurvinton et al. 1992). We therefore suggested that the $\omega$ region of VirD2 may be involved in T-DNA integration. We report here additional experiments that indicate that the $\omega$ region of VirD2 is involved in the efficiency, but not the pattern, of T-DNA integration. We additionally report the effect of various VirD2 NLS and $\omega$ mutations on T-DNA transfer and nuclear targeting.

\section{RESULTS}

A T-DNA-encoded gusA gene is transcribed early after infection of tobacco cells with $A$. tumefaciens VirD2 NLS and $\omega$ mutants.

To investigate the importance of various domains of the $A$. tumefaciens VirD2 protein in T-DNA transfer to the plant cell and T-DNA nuclear targeting, we used reverse transcriptionpolymerase chain reaction (RT-PCR) to detect early transcription of the T-DNA (Narasimhulu et al. 1996). We infected tobacco BY-2 suspension culture cells with various A. tumefaciens VirD2 mutant strains harboring the binary T-DNA vector pBISN2 (Narasimhulu et al. 1996). This binary vector contains a gusA-intron gene under the transcriptional control of a very strong synthetic promoter (composed of a trimer of the octopine synthase activating element affixed to the mannopine synthase $2^{\prime}$ activating element plus minimal promoter; $\mathrm{Ni}$ et al. 1995). At various times after infection, we isolated total plant RNA and assayed for the expression of the processed gusA mRNA.

Figure 1A shows that tobacco cells infected by wild-type $A$. tumefaciens At822 first produced detectable gusA mRNA $18 \mathrm{~h}$ after infection. The amount of gusA mRNA (detectable as a 543-bp PCR product) gradually increased, peaked at $36 \mathrm{~h}$, and subsequently declined. Figure $1 \mathrm{C}$ indicates that tobacco cells infected by A. tumefaciens At829 showed a similar pattern of gusA mRNA accumulation. This strain encodes a mutant VirD2 protein in which four of the five $\omega$ domain amino acids are replaced by two serines (Shurvinton et al. 1992). The results of quantitative PCR analysis (Narasimhulu et al. 1996) reported in Table 1 show that, at $36 \mathrm{~h}$ after infection, tobacco cells infected with the virD2 $\omega$ deletion/substitution mutant accumulated $20 \%$ of the level of gusA mRNA of cells infected with a strain containing a wild-type virD2 gene. These results were reproducible for sets of RNAs extracted from cells of two separate infections. These patterns and relative amounts of gusA mRNA accumulation closely resemble the values previously reported (Narasimhulu et al. 1996).

Figure 1B and Table 1 show that tobacco cells infected by A. tumefaciens At827, which contains a mutant virD2 gene lacking both parts of the bipartite NLS, accumulate gusA mRNA to the same level as cells infected with the wild-type A. tumefaciens strain. This result indicates that the VirD2 Cterminal bipartite NLS is not essential for T-DNA nuclear transport. We suggest that NLS sequences in VirE2 can target T-strands to the nucleus efficiently. The relatively high level of gusA mRNA accumulation in tobacco cells infected with $A$. tumefaciens At827 correlates well with the relatively high level of tumorigenesis (60\% of the wild-type value) on potato disks inoculated with an A. tumefaciens strain harboring the same NLS mutation (Shurvinton et al. 1992).

Finally, we infected tobacco cells with A. tumefaciens At823. This strain contains a large deletion in virD2 $(\Delta \mathrm{NruI})$ that eliminates the C-terminal NLS and an additional 23 amino acids upstream of the NLS sequence. Shurvinton et al. (1992) showed that the virulence of this strain is extremely attenuated (1 to $4 \%$ the level of wild type). In accord with their result, we were unable to detect gusA mRNA in tobacco cells infected with this strain (Fig. 1D and Table 1). T-strands accumulate within the bacteria to approximately wild-type levels, however, in A. tumefaciens strains harboring this virD2 
$\Delta$ NruI deletion (Shurvinton et al. 1992). Taken together, the data of Shurvinton et al. and the data presented here suggest that tumorigenesis by this mutant strain is blocked at an early step in the transformation process, most likely either at TDNA transfer to the plant or T-DNA nuclear transport.

We sampled tobacco cells infected with the different virD2 mutant strains at various times after infection and stained them with 5-bromo-4-chloro-3-indolyl $\beta$-Dglucuronic acid (X-gluc) to determine the percentage of cell clusters that expressed $\beta$-glucuronidase (GUS) activity. Table 2 shows that when tobacco cell clusters were infected with strain At827 harboring the $\triangle \mathrm{NLS}$ virD2 mutation, the percentage of cell clusters showing detectable GUS staining eventually reached $0.12 \%$, which is half the number of

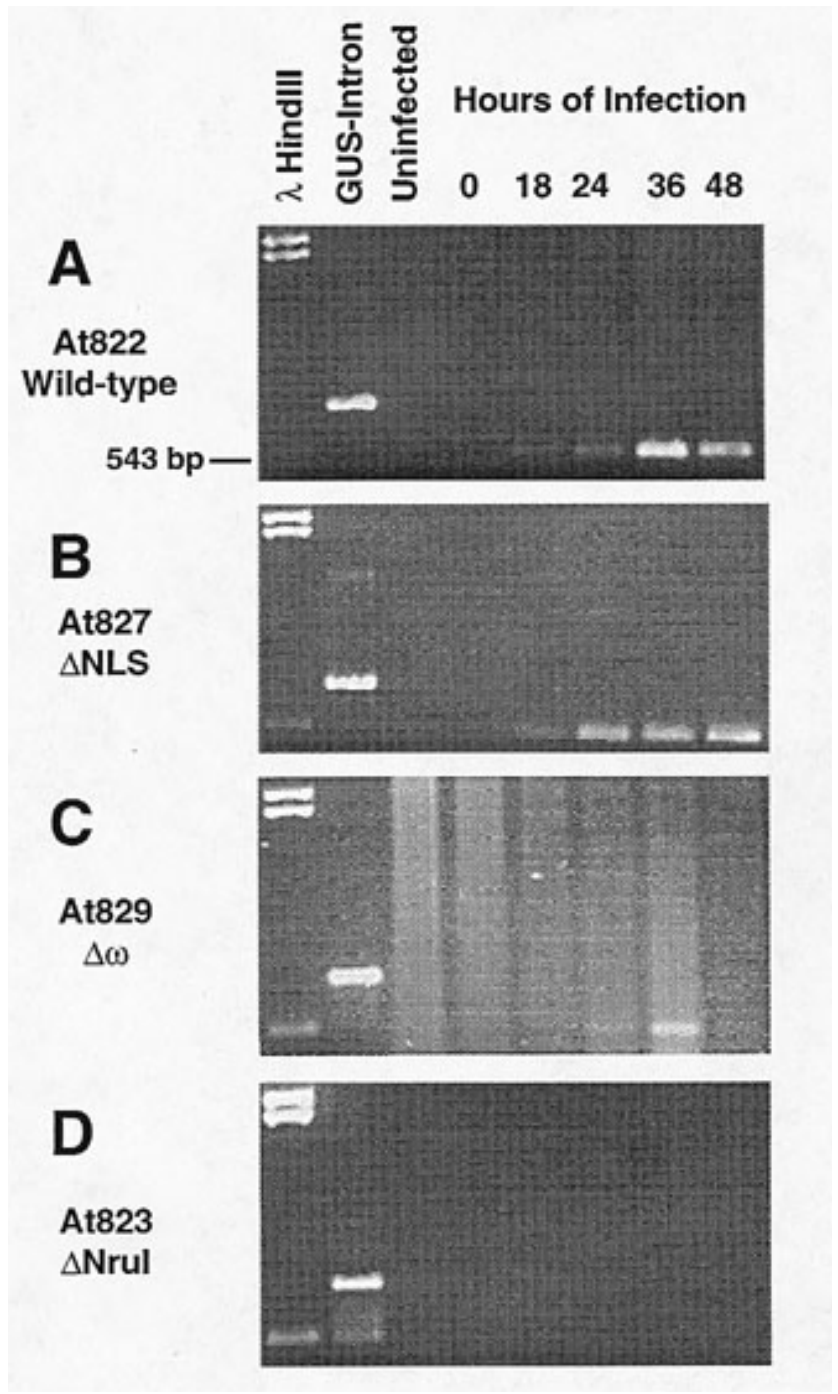

Fig. 1. Early expression of a gusA gene in tobacco BY-2 cells after infection by Agrobacterium tumefaciens virD2 wild-type and mutant strains. Tobacco suspension cell cultures were infected with different $A$. tumefaciens strains. After $0,18,24,36$, or $48 \mathrm{~h}$, RNA was isolated and analyzed for the presence of processed gusA transcripts by reverse transcription-polymerase chain reaction (RT-PCR) as described in Materials and Methods. A. tumefaciens (A) At822, (B) At827, (C) At829, (D) At823. $\lambda$ HindIII, length standards of bacteriophage $\lambda$ DNA digested with HindIII; $\beta$-glucuronidase (GUS)-intron, PCR amplification of a 732-bp gusA-intron gene.
GUS-positive cell clusters produced by infection with a wild-type strain. This level of GUS expression correlates well with the $60 \%$ level of virulence displayed by a similar virD2 $\triangle$ NLS mutant strain (Shurvinton et al. 1992). However, tobacco cells infected with strain At829, harboring the $\omega$ deletion/substitution virD2 allele, only occasionally $(<0.01 \%$ of the cell clusters examined) expressed detectable GUS staining. These results agree with our previous observations (Narasimhulu et al. 1996) and indicate that, although early expression of the gusA gene in these cells is relatively efficient ( $20 \%$ that of the wild-type virD2 gene), stable expression of GUS activity is rare. Our observations further suggest that infection of plant cells with strains harboring the $\omega$ deletion/substitution virD2 allele does not result in the efficient, stable expression of T-DNA-encoded traits, perhaps because T-DNA transferred from these mutant strains cannot efficiently integrate into the plant genome. Finally, Table 2 shows that tobacco cells infected with strain At823 $(\Delta \mathrm{NruI} v i r D 2$ deletion) did not stain with $\mathrm{X}$-gluc.

\section{Long-term kinetics of GUS expression in tobacco cells infected with $A$. tumefaciens containing wild-type and $\omega$-mutant virD2 genes.}

To investigate the importance of the VirD2 $\omega$ domain on the long-term stability of GUS expression in transformed tobacco cells, we infected BY-2 suspension cultures separately with $A$. tumefaciens At822 (wild-type virD2), At829 ( $\omega$ deletion/substitution virD2), or At894 (lacking a Ti plasmid). Cocultivation for $48 \mathrm{~h}$ before adding antibiotics greatly increased the efficiency of infection, compared with 12-h cocultivations used in the experiments described above. Figure 2 shows the kinetics of GUS expression as determined by $\mathrm{X}$ gluc staining. When tobacco cells were incubated with strain At822 containing the wild-type virD2 gene, we detected blue staining of $2 \%$ of the cell clusters 1.5 days after the initiation of infection. The percentage of cell clusters showing detectable GUS staining increased rapidly and peaked at 4 to 5 days after the start of cocultivation. At this time, $20 \%$ of the cell clusters stained blue. After day 5, the percentage of bluestained cell clusters declined rapidly, and at day 14 only $0.6 \%$

Table 1. Quantitation of gusA mRNA by reverse transcriptionpolymerase chain reaction $36 \mathrm{~h}$ after infection

\begin{tabular}{lcc}
\hline Agrobacterium tumefaciens strain & virD2 allele & $\begin{array}{c}\text { gusA mRNA (pg)/ } \\
\text { total cell RNA ( } \boldsymbol{~ m g})\end{array}$ \\
\hline At822 & Wild type & 0.25 \\
At827 & $\Delta$ NLS & 0.25 \\
At829 & $\Delta \omega$ & 0.05 \\
At 823 & $\Delta$ NruI & Not detectable \\
\hline
\end{tabular}

Table 2. Percentage of tobacco BY-2 cell clusters exhibiting $\beta$ glucuronidase (GUS) activity

\begin{tabular}{llrrrrrr}
\hline $\begin{array}{l}\text { Agrobacterium } \\
\text { tumefaciens } \\
\text { strain contain- }\end{array}$ & & \multicolumn{5}{c}{ Days after infection } \\
ing pBISN2 & virD2 allele & $\mathbf{2}$ & $\mathbf{2 . 5}$ & $\mathbf{3}$ & $\mathbf{4}$ & $\mathbf{5}$ \\
\hline At822 & Wild-type & 0.04 & 0.12 & 0.13 & 0.23 & 0.23 \\
At827 & $\Delta$ NLS & 0.00 & 0.05 & 0.03 & 0.13 & 0.12 \\
At829 & $\Delta \omega$ & 0.00 & 0.00 & 0.00 & $<0.01$ & $>0.00^{\mathrm{a}}$ \\
At823 & $\Delta$ NruI & 0.00 & 0.00 & 0.00 & 0.00 & 0.00 \\
\hline
\end{tabular}

${ }^{a}$ Blue-stained cells were occasionally observed. 
of the cell clusters stained blue. After 14 days and until 42 days (the last time point investigated), the percentage of bluestained cell clusters stabilized at 0.4 to $0.6 \%$.

Figure 2 also shows that when we infected tobacco cells with the virD2 $\omega$ mutant strain At829, the percentage of GUSstained cell clusters also peaked at 4 days, when $4 \%$ of the cell clusters were stained blue. The percentage of cell clusters stained blue then decreased until, by 12 days after infection, GUS staining was almost undetectable. We obtained similar results with $A$. thaliana cell cultures (data not shown). Both tobacco and A. thaliana cell cultures infected with A. tumefaciens At894 (lacking a Ti plasmid) did not show any blue staining (data not shown). For each of the samples taken for the experiment described above, we observed at least 10,000 cell clusters.

Our results indicate that after infection of tobacco cells with the wild-type strain At822, 2 to $3 \%$ of the cell clusters that initially (4 day time point) showed transient GUS staining ultimately showed stable GUS expression. Tobacco cells in-

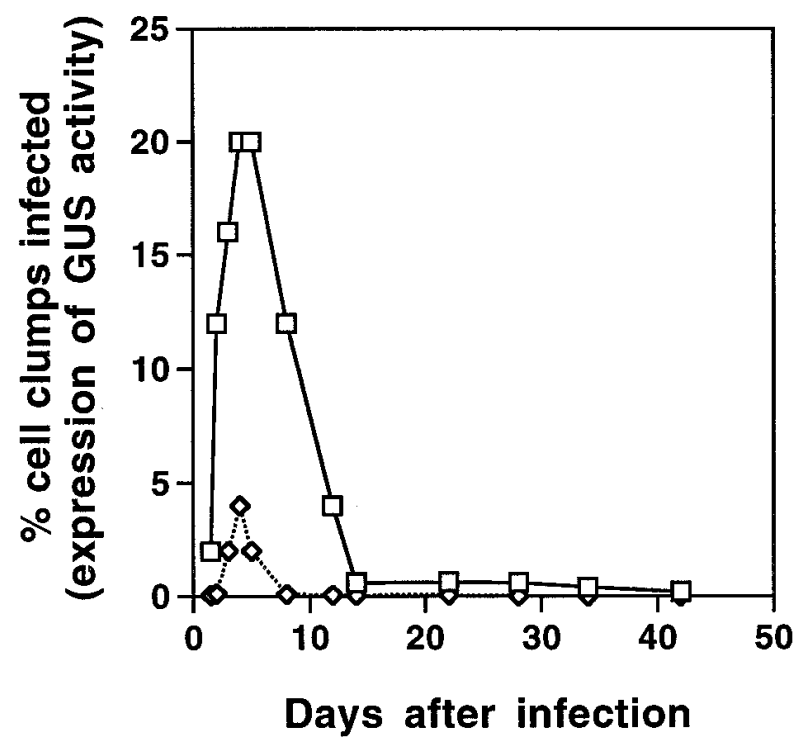

Fig. 2. Kinetics of $\beta$-glucuronidase (GUS) expression in tobacco BY-2 suspension cells. Tobacco suspension cell cultures were infected with Agrobacterium tumefaciens strains containing either the wild-type virD2 (At822) or the $\omega$ mutant virD2 (At829) gene. Cells were sampled at various times after infection, stained with 5-bromo-4-chloro-3-indolyl $\beta$ D-glucuronic acid (X-gluc), and the percentage of cell clusters staining blue was determined. Open box, A. tumefaciens At822. Open diamond, A. tumefaciens At829. fected with the virD2 $\omega$ mutant initially showed only $20 \%$ of the number of blue-stained cell clusters showed by BY-2 cells infected with the wild-type strain (a number consistent with the RT-PCR and X-gluc staining data presented in Figure 1, Table 1, and Narasimhulu et al. 1996). However, we could not detect stable GUS staining in these cells. These results indicate that cells infected by this virD2 $\omega$ mutant cannot stabilize GUS expression and further suggest that the $\omega$ region of VirD2 is important for T-DNA integration.

\section{A wild-type, but not an $\omega$ mutant, virD2 A. tumefaciens strain can induce GUS expression in tobacco cells transformed by a "promoter trap" T-DNA.}

We constructed a T-DNA binary vector, pKM1, that could direct the expression of GUS activity in plants only after integration of the T-DNA downstream of a plant promoter. pKM1 contains a T-DNA right border sequence adjacent to the $5^{\prime}$ end of a promoterless gusA-intron gene. This plasmid also contains a luciferase $(l u c)$-intron gene under the control of the cauliflower mosaic virus (CaMV) $35 \mathrm{~S}$ promoter. Figure 3 presents a map of pKM1. We mobilized this plasmid into $A$. $t u$ mefaciens to generate strains At899 (containing a wild-type virD2 gene) and At898 (containing a virD2 $\omega$ deletion/substitution mutation), and used these strains to inoculate tobacco BY-2 cell cultures.

Table 3 shows that only tobacco cells transformed by $A$. $t u$ mefaciens At899 expressed GUS activity. Approximately 0.32 to $0.40 \%$ of these cell clusters stained blue with X-gluc. Cells infected with the virD2 $\omega$ mutant strain At898 did not express GUS activity. For each of the samples taken for the experiment described above, we observed at least 5,000 cell clusters. To test whether strain At898 transferred T-DNA to tobacco nuclei, we assayed expression of the T-DNA-encoded luc gene by RT-PCR. Figure 4 shows that luciferase transcripts with the intron spliced out accumulated to a maximal extent $36 \mathrm{~h}$ after infection, after which their levels declined. The pattern of $l u c$ mRNA accumulation closely resembled that of gusA mRNA accumulation shown in Figure 1C.

Our results indicate that although an A. tumefaciens strain that contains this virD2 $\omega$ mutation could transfer T-DNA to tobacco nuclei and transiently express a luc gene that contains a promoter, it could not do so with a gusA gene that required integration into the plant genome for expression. These data further suggest that the $\omega$ domain of VirD2 is required for efficient T-DNA integration into plant DNA.

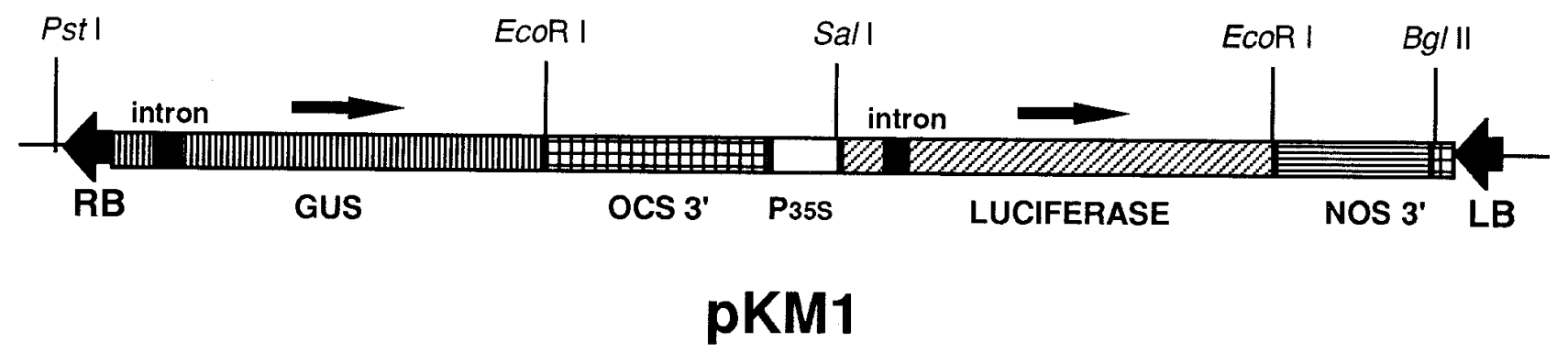

Fig. 3. Map of the promoter trap plasmid pKM1. RB, T-DNA right border; LB, T-DNA left border; intron, potato ST-LS1 gene intron (Vancanneyt et al. $1990)$; GUS ( $\beta$-glucuronidase), gusA coding region; OCS 3', octopine synthase polyadenylation signal sequence; $\mathrm{P}_{35 \mathrm{~s}}$, cauliflower mosaic virus $(\mathrm{CaMV})$ $35 \mathrm{~S}$ promoter; LUCIFERASE, luc coding region; NOS 3', nopaline synthase polyadenylation signal sequence. 


\section{An A. tumefaciens virD2 $\omega$ mutant strain is deficient in T-DNA integration.}

We infected $A$. thaliana suspension cell cultures separately with A. tumefaciens At822 (wild-type virD2), At829 ( $\omega$ deletion/substitution virD2 mutant), or At894 (no Ti plasmid). After 2 days of cocultivation, we added antibiotics to the medium to kill the bacteria and continued to grow the plant cells in the presence of phytohormones and antibiotics. Because of the presence of phytohormones in the medium, tumor cells would not outgrow the uninfected cells. We transferred these cells several times for a period of greater than 1 month to assure that all A. tumefaciens cells were killed, and that DNA from any remaining dead cells would be diluted from the culture. After 40 days of growth, we isolated high-molecularweight DNA from these cultures and assayed for the integration of the T-DNA-encoded gusA gene by DNA gel blot analysis. Figure 5A shows that T-DNA integrated into highmolecular-weight plant DNA of $A$. thaliana cells infected by strain At822 containing a wild-type virD2 gene. However, we could not detect T-DNA integrated into the genome of $A$. thaliana cells infected with the virD2 $\omega$ mutant strain At829. As expected, we could not detect T-DNA integrated into the genome of A. thaliana cells infected with strain At894 lacking a Ti plasmid, or in uninfected cells. In order to assure that equal amounts of DNA were loaded onto each gel lane, we washed the gusA probe from the membrane and rehybridized the blot with an $A$. thaliana phenylalanine ammonia-lyase (PAL) gene. Figure 5B shows that equal amounts of DNA were present in each gel lane. These data show that plant cells infected with an A. tumefaciens strain lacking the $\omega$ domain of VirD2 do not efficiently integrate T-DNA into their genomes.

\section{A VirD2 $\omega$ mutation does not affect the pattern of T-DNA integration.}

Although A. tumefaciens strains harboring the virD2 $\omega$ deletion/substitution mutation are severely attenuated in virulence, they are not avirulent. Shurvinton et al. (1992) showed that such a strain was able to induce crown gall tumors on potato disks, but with only $3.3 \%$ the efficiency of a wild-type strain. To investigate whether this $\omega$ mutation altered the pattern of T-DNA integration, we incited tumors on tobacco leaf disks with strains At747 (containing a wild-type virD2 gene) and At746 (containing the $\omega$ deletion/substitution virD2 gene). Infection of tobacco leaf disks with strain At746 resulted in 0.06 tumors per disk, compared with 2.3 tumors per disk for strain At747.

When T-DNA integrates into plant DNA, the right junction between bacterial DNA and plant DNA almost always occurs

Table 3. Percentage of tobacco BY-2 cell clusters exhibiting $\beta$ glucuronidase (GUS) activity

\begin{tabular}{lcc}
\hline \multirow{2}{*}{$\begin{array}{l}\text { Days after } \\
\text { infection }\end{array}$} & \multicolumn{2}{c}{ Agrobacterium tumefaciens strain containing pKM1 } \\
\cline { 2 - 3 } & At899 (wild-type virD2) & At898 $(\boldsymbol{\omega}$ mutant virD2) \\
\hline 2 & $0.04(2)^{\mathrm{a}}$ & $0.00(0)$ \\
3 & $0.32(16)$ & $0.00(0)$ \\
4 & $0.36(18)$ & $0.00(0)$ \\
5 & $0.40(20)$ & $0.00(0)$ \\
6 & $0.36(18)$ & $0.00(0)$ \\
8 & $0.36(18)$ & $0.00(0)$ \\
\hline
\end{tabular}

a Numbers in parenthesis indicate number of blue-stained cell clusters from a total of 5,000 cell clusters observed. precisely at the base where VirD2 nicks the right border; in contrast, the left junction between bacterial and plant DNA frequently does not occur within the left border sequence (Tinland and Hohn 1993; Tinland et al. 1995; Rossi et al. 1996). We therefore used the PCR to analyze T-DNA sequences near the right border. First, however, we used the PCR and primers specific for the tms oncogenes (Yusibov et al. 1994) to assure that all calli contained T-DNA. Figure 6C shows that all tumorous calli contained this oncogene. We then analyzed the tumors for the presence of the picA gene. picA is contained on the A. tumefaciens chromosome (Rong et al. 1990). The presence of picA sequences in the tumor DNA would indicate that this plant DNA contained DNA from contaminating A. tumefaciens cells. We previously showed that the sensitivity of detection of picA sequences was at least as great as our ability to detect tms sequences with this technique (Yusibov et al. 1994). Figure 6D shows that we could not detect picA sequences among the tumors investigated. Therefore, T-DNA border sequences detected in tumor DNA resulted from integrated T-DNA and not from contaminating bacterial DNA.

To determine whether the right T-DNA/plant DNA junction extended to the VirD2 nick site in the right border or whether T-DNA sequences at the right border junction had been truncated as a result of the VirD2 $\omega$ mutation, we synthesized primers homologous to the T-DNA at various distances from this border, as shown in Figure 6A. Primer rb1 extends leftward from the nucleotide immediately to the left of the VirD2 nick site, rb2 contains sequences within the T-DNA 35 bp from the RB, rb3 has sequences within the T-DNA still further from the RB, etc. Primer rb6 is homologous to T-DNA sequences beginning $869 \mathrm{bp}$ to the left of the right border and extends in the opposite orientation from primers rb1 to rb5 (Fig. 6A).

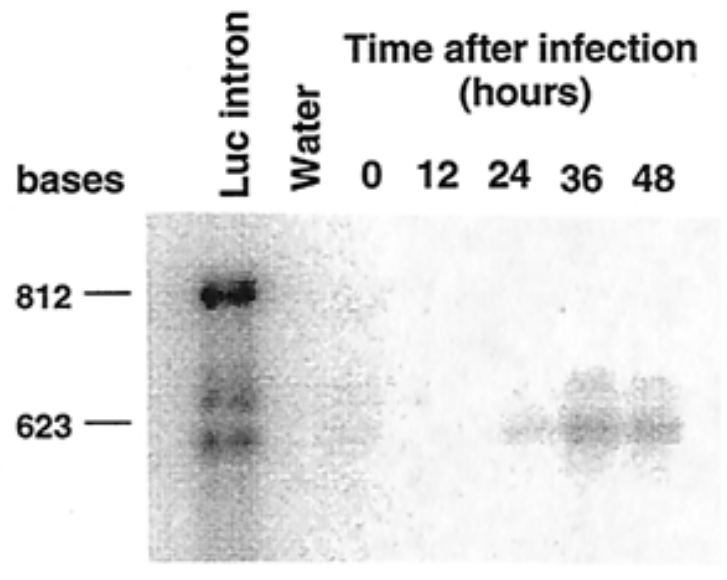

Fig. 4. Early expression of the luciferase (luc) gene encoded by the promoter trap vector pKM1 in tobacco BY-2 cells infected by Agrobacterium strain At898. Tobacco suspension cell cultures were infected with Agrobacterium strain At898 ( $\omega$ mutant virD2) harboring the promotertrap binary vector pKM1. RNA was isolated from samples taken at various times after infection and subjected to reverse transcriptionpolymerase chain reaction (RT-PCR) with primers that flank the lucintron region. Amplification products (623 bp for the processed mRNA) were subjected to electrophoresis through a $1.2 \%$ agarose gel, blotted onto a nylon membrane, and hybridized with a luc gene probe. Luc intron, amplification of the $l u c$-intron gene ( $812 \mathrm{bp}$ amplification product) from pKM1. Water, no RNA added to the amplification mix. 
PCR analysis of 27 tumors that were produced by A. tumefaciens At747 with wild-type virD2 resulted in the amplification of the expected 869-bp fragment with primers rb1 and rb6. Of the 43 tumors produced by the virD2 $\omega$ mutant strain At746, all also showed this amplification product (Fig. 6B). These results indicate that, within the limitations of this PCR technique, the virD2 $\omega$ mutant preserved the right T-DNA end upon integration as well as the wild-type strain did. Thus, the virD2 $\omega$ deletion/substitution mutation affects the efficiency but not the precision of T-DNA integration.

\section{A VirD2 $\omega$ deletion mutant protein cleaves} the right border efficiently and correctly in vitro.

We purified wild-type VirD2 protein and a mutant protein, $\Delta \omega$ VirD2 (which lacks the five $\omega$ amino acids plus the terminal threonine residue), from Escherichia coli and tested these proteins for their ability to cleave a DNA fragment containing a T-DNA right border sequence in vitro. Figure 7 shows that each protein cleaved a 530 nucleotide, singlestranded DNA segment (uniformly labeled with ${ }^{32} \mathrm{P}$ ) between nucleotides 3 and 4 within the right T-DNA border, resulting in the production of a 460 nucleotide, labeled fragment. The $\Delta \omega$ VirD2 protein was at least as active in this cleavage as the wild-type VirD2 protein was. We con- clude that the $\omega$ domain of VirD2 is not required for in vitro cleavage of a T-DNA border sequence.

\section{Mutation analysis of the VirD2 bipartite NLS and the $\omega$ region in nuclear transport.}

The C-terminal region of VirD2 contains a bipartite NLS upstream of the $\omega$ domain that, when fused to the $\mathrm{C}$ terminus of GUS, can target the fusion protein to the nucleus of plant and yeast cells (Howard et al. 1992; Tinland et al. 1992; Rossi et al. 1993). Previous analyses of this NLS involved the generation of mutations that altered the charge of the protein. In addition, the role of the $\omega$ domain in nuclear targeting was unknown because all GUS-VirD2 NLS fusions previously tested contained $\omega$. We therefore investigated further the importance of amino acids in this region of VirD2 in targeting a GUS fusion protein to tobacco nuclei. We generated several mutations affecting the C-terminal region of VirD2. Figure 8 shows the amino acid sequence of this region of VirD2, and the sequences of the various mutant proteins. In all polypeptides with mutant NLS domains, amino acid substitutions did not change the number or polarity of charged residues within the NLS domain. We created substitution mutations in each half of the bipartite NLS, in both halves of the NLS, in the spacer region between the two NLS components, and in the

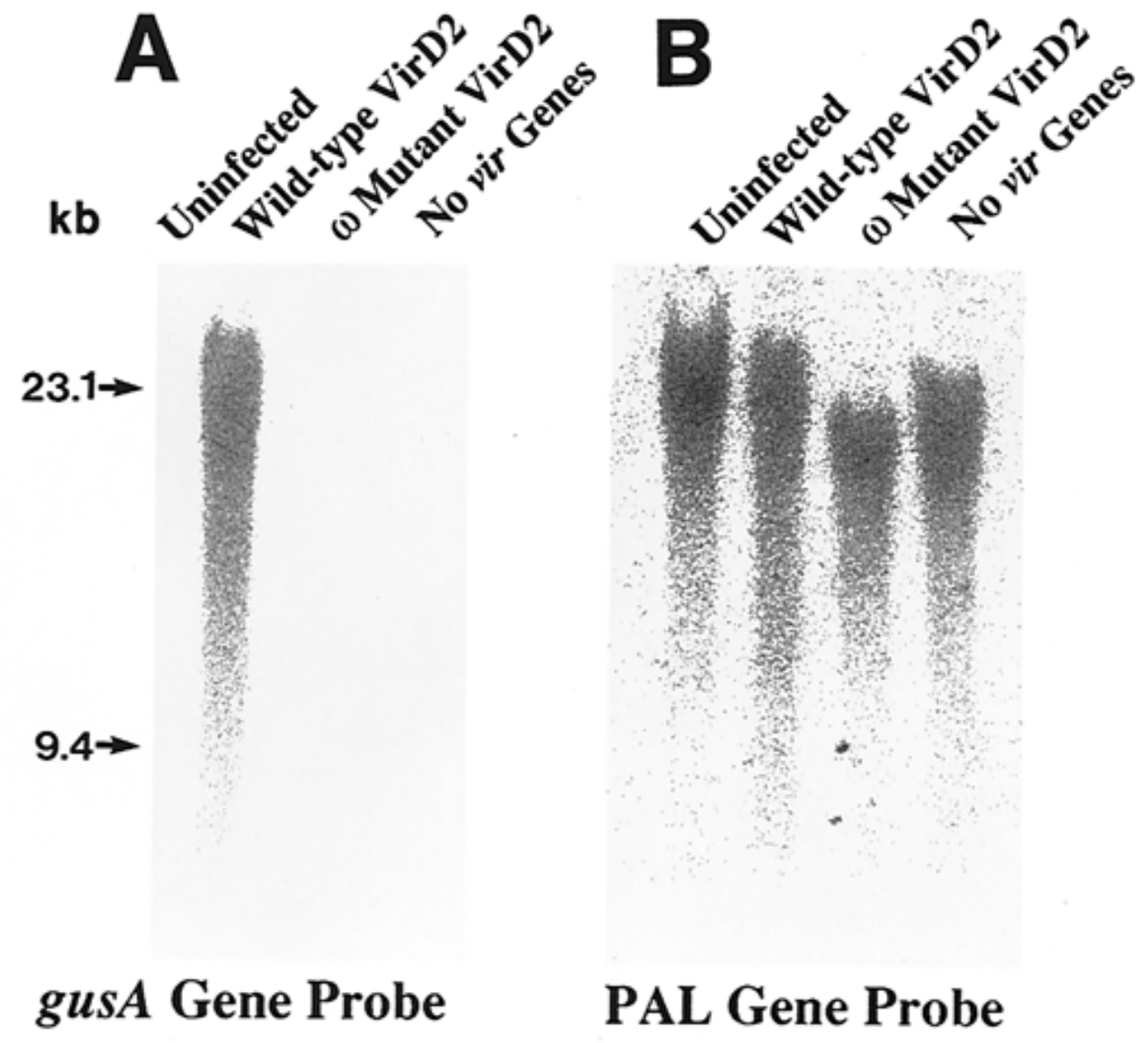

Fig. 5. Effect of the virD2 $\omega$ region on T-DNA integration in Arabidopsis thaliana suspension cells. A. thaliana suspension cells were cocultivated with Agrobacterium tumefaciens strains containing the wild-type virD2 gene (At822), an $\omega$ mutant virD2 gene (At829), or lacking a tumor-inducing (Ti) plasmid (no vir genes, At894). After 2 days, the cells were washed and resuspended in medium containing antibiotics to kill the bacteria. Highmolecular-weight plant DNA was extracted from cells 42 days after infection, or from uninfected cells. Undigested DNA ( $5 \mu \mathrm{g})$ was blotted onto a nylon membrane and hybridized with (A) the gusA gene probe, $(\mathbf{B})$ an A. thaliana phenylalanine ammonia-lyase (PAL) gene probe. kb, DNA size markers of bacteriophage $\lambda$ DNA digested with HindIII. 
entire region containing both bipartite NLS components. We also tested a deletion mutation precisely eliminating the five $\omega$ amino acids but maintaining the wild-type NLS intact. We placed the gusA-virD2 fusion genes under the control of the CaMV 35S promoter and electroporated the constructions into tobacco protoplasts to study the role of each domain in the nuclear transport of GUS-NLS fusion proteins. We quantitated nuclear targeting by calculating the percentage of tobacco cells that, when stained with X-gluc, showed GUS activity exclusively in the nucleus.

Figures 9 and 10 indicate that when the VirD2 NLS was not fused to the GUS protein, only $8 \%$ of the cells showed GUS activity in the nucleus; $92 \%$ of the cells showed GUS activity exclusively in the cytoplasm. When the wild-type VirD2 NLS was fused to the GUS protein, $87 \%$ of the cells localized GUS activity exclusively in the nucleus. When either of the NLS domains was individually mutated, the percentage of cells showing exclusive nuclear localization of GUS activity was reduced to approximately $70 \%$. Mutation of both components of the bipartite NLS further reduced exclusive nuclear localization of GUS activity to $27 \%$ of the cells. Mutation of the entire region containing both components of the C-terminal bipartite NLS reduced nuclear localization of GUS activity to $10 \%$ of the cells, a number equivalent to that when no NLS was affixed to the GUS protein. Mutation of three of the 10
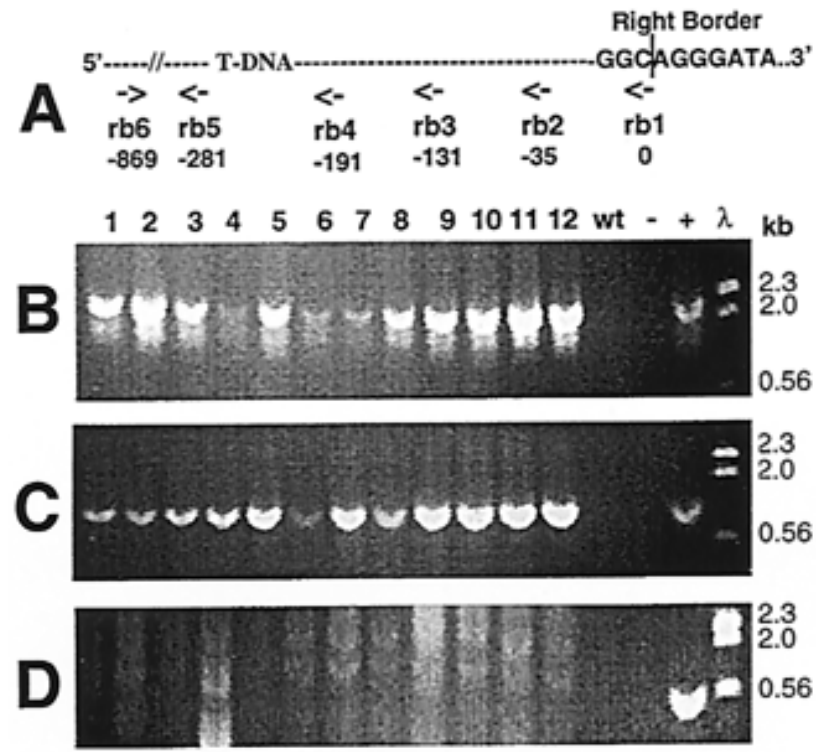

Fig. 6. Polymerase chain reaction (PCR) amplification of DNA from tumors generated by infection of tobacco with wild-type and $\omega$ virD2 mutant Agrobacterium tumefaciens strains. DNA was isolated from tumors generated by infection of tobacco leaf disks with the $\omega$ mutant virD2 A. tumefaciens At746. DNA was subjected to the PCR with various primer combinations. Amplified products were analyzed by agarose gel electrophoresis. Lanes 1 to 12, the amplified DNA from different tumors. wt, amplification product from nontransformed W38 tobacco DNA; -, amplification product from a sample lacking DNA; +, amplification product from total DNA of $A$. tumefaciens At747; $\lambda$, molecular size markers from bacteriophage $\lambda$ digested with HindIII. A, Position and orientation of primers $\mathrm{rb} 1$ to $\mathrm{rb} 6$ in the T-DNA $\mathrm{T}_{\mathrm{L}}$ right border region of pTiA6. 0, position of nick site in the border. Other numbers (-x), distance (in nucleotides) of $5^{\prime}$ end of primers from right border nick site. B, Amplification products with rb1 and rb6 primers. C, Amplification products with tms primers. D, Amplification products with picA primers. amino acids in the spacer region between the two components of the bipartite NLS had virtually no affect upon nuclear targeting. Similarly, complete deletion of the $\omega$ region did not affect the nuclear localization of GUS activity. We conducted electroporation experiments for each construction at least three times, and counted 300 to 600 blue-stained cells for each construction.

Our analysis indicates that the $\omega$ domain of VirD2 is not involved in nuclear targeting. As shown by others (Howard et al. 1992), each component of the bipartite NLS by itself has some nuclear targeting activity.

\section{DISCUSSION}

VirD2 contains a number of domains involved in T-DNA processing, nuclear targeting, and integration. The $\mathrm{N}$-terminal half of the protein contains an endonuclease activity and, along with VirD1 protein, is sufficient to cleave T-DNA borders in both E. coli and A. tumefaciens (Yanofsky et al. 1986; Jayaswal et al. 1987; Stachel et al. 1987; Filichkin and Gelvin 1993). The $5^{\prime}$ end of the resulting single-stranded DNA (the Tstrand) becomes linked to VirD2 through a tyrosine residue near the amino terminus of the protein (Herrera-Estrella et al. 1988; Ward and Barnes 1988; Young and Nester 1988; Howard et al. 1989; Vogel and Das 1992). Although A. tumefaciens strains harboring a mutant VirD2 protein lacking the C-terminal half of the molecule accumulate T-strands upon induction with acetosyringone (Stachel et al. 1987), they are avirulent (Stachel and Nester 1986; Koukolikova-Nicola et al. 1993). This result indicates that the C-terminal portion of

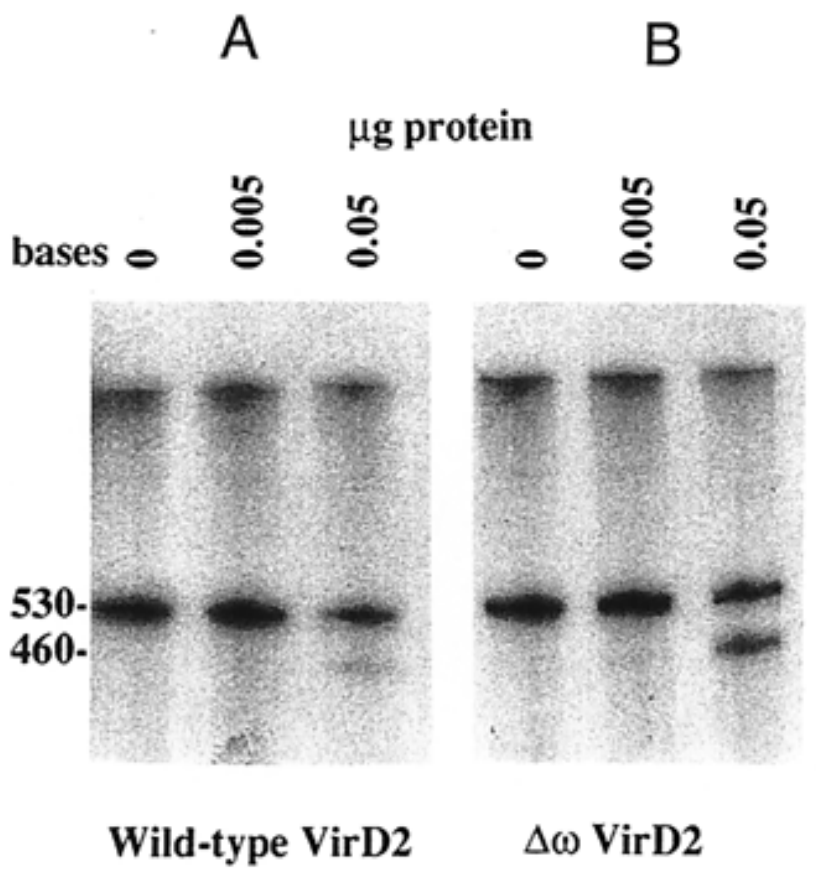

Fig. 7. In vitro cleavage of a T-DNA right border with wild-type VirD2 and $\Delta \omega$ VirD2 proteins. A uniformly labeled, 530-base, single-stranded DNA fragment containing the right T-DNA border sequence was incubated with various amounts of either wild-type VirD2 or the $\Delta \omega$ mutant VirD2 protein. After electrophoresis through a $4 \%$ polyacrylamide gel, the 460-base cleavage product was detected by autoradiography. A, Wild-type VirD2 protein. B, $\Delta \omega$ VirD2 protein. 
VirD2 contains information essential for the later processes of A. tumefaciens-mediated transformation. These processes may include T-strand export from the bacterium to the plant cell, nuclear targeting of the T-DNA, and/or T-DNA integration into the plant genome.

VirD2 contains an N-terminal, monopartite NLS that, when linked to a reporter protein, can direct the fusion protein to the nucleus of plant and yeast cells (Herrera-Estrella et al. 1990; Tinland et al. 1992). However, this NLS does not contribute to targeting of the T-DNA to the nucleus (Shurvinton et al. 1992; Rossi et al. 1993), most likely because it is occluded by the Tstrand that is attached to the tyrosine residue near this NLS. VirD2 also contains a C-terminal, bipartite NLS and a region called $\omega$. The $\omega$ domain consists of five penultimate, highly conserved amino acids and is not part of a known NLS motif. A. tumefaciens strains harboring a $\omega$ deletion/substitution mutation or some C-terminal NLS mutations are either avirulent or severely attenuated in virulence (Stachel and Nester 1986; Shurvinton et al. 1992; Koukolikova-Nicola et al. 1993). We have investigated which $\operatorname{step}(\mathrm{s})$ in the transformation process are blocked by these mutations.

\section{The C-terminal NLS and $\omega$ sequences of VirD2 are not essential for T-DNA transfer to the plant cell or nuclear targeting.}

Shurvinton et al. (1992) showed that precise deletion of both components of the VirD2 C-terminal NLS reduced the virulence of $A$. tumefaciens on potato disks by approximately $40 \%$. Using the identical NLS deletion in a strain harboring the gusA-intron plasmid pBISN2, we showed that, by 4 days after infection, the percentage of tobacco cell clusters stained blue with X-gluc was approximately $50 \%$ of that seen when a strain harboring a wild-type virD2 gene was used (Table 2). Moreover, when we used a sensitive RT-PCR assay to monitor transcription of the gusA-intron gene in tobacco cells only 36 $\mathrm{h}$ after infection, we detected the same level of processed gusA mRNA with the $\triangle$ NLS mutant as we did with a wildtype strain (Fig. 1, Table 1). These results indicate that the TDNA transfer and nuclear targeting efficiencies of this $\triangle$ NLS and the wild-type VirD2 proteins are (within a factor of 2) approximately the same. Although we do not know whether Xgluc staining of tobacco cells 4 to 5 days after infection represents expression of integrated or nonintegrated T-DNA molecules, our results indicate that the VirD2 C-terminal NLS is not essential for either T-DNA transfer or nuclear targeting. We suggest that deletion of the C-terminal NLS of VirD2 may be compensated by the NLS domains within VirE2 protein molecules that presumably coat T-strands in the plant cell (Citovsky et al. 1992).

Because deletion of the NLS domains did not markedly affect T-DNA transfer or nuclear targeting, we investigated the effect of larger deletions of this region of VirD2. When we used an $A$. tumefaciens strain containing the $\Delta \mathrm{NruI}$ mutation of virD2, in which the C-terminal NLS domain is deleted along with 23 amino acids upstream, we did not detect gusA transcripts or X-gluc staining of infected tobacco cells (Fig. 1, Tables 1 and 2). These results are consistent with the data of Shurvinton et al. (1992), who showed that an A. tumefaciens strain harboring this same $\Delta \mathrm{NruI}$ virD2 mutation showed extremely low virulence. T-DNA processing in this strain is normal (Shurvinton et al. 1992). These results indicate that

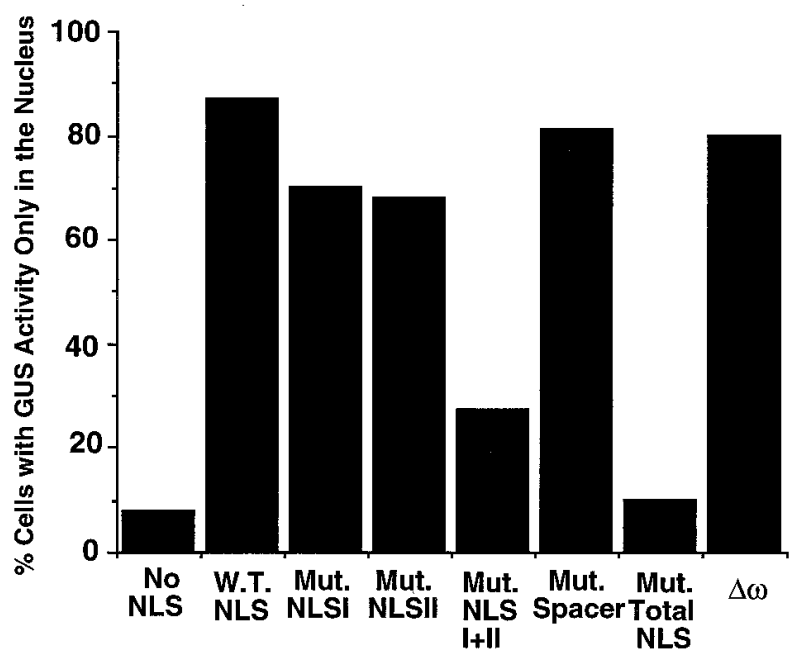

Fig. 9. Nuclear localization of $\beta$-glucuronidase (GUS) activity in tobacco protoplasts electroporated with wild-type and mutant gusA-virD2 fusion genes. Tobacco protoplasts were electroporated with gusA plasmids either lacking the VirD2 bipartite nuclear localization sequence (NLS) or containing wild-type or mutant VirD2 NLS and $\omega$ regions. Cells were stained with 5-bromo-4-chloro-3-indolyl $\beta$-D-glucuronic acid (X-gluc) $20 \mathrm{~h}$ after electroporation, and the percentage of cells showing GUS activity exclusively in the nucleus was determined.

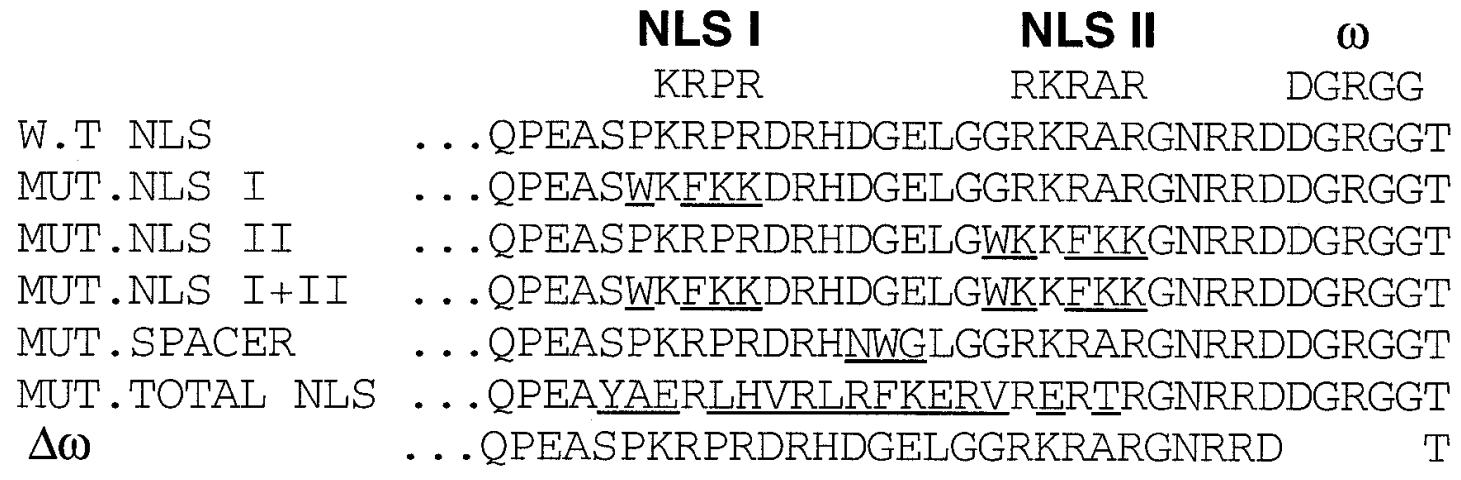

Fig. 8. Amino acid substitution mutations within C-terminal region of VirD2 protein. W.T. NLS, sequence of C-terminal region of wild-type VirD2 protein. Below this sequence are the sequences of the mutant VirD2 proteins. Amino acids altered from the wild-type sequence are underlined. In $\Delta \omega$, the five amino acids of the $\omega$ domain are deleted. Amino acids defining the NLS I, NLS II, and $\omega$ domains are noted above the wild-type sequence. 


\section{NO NLS}

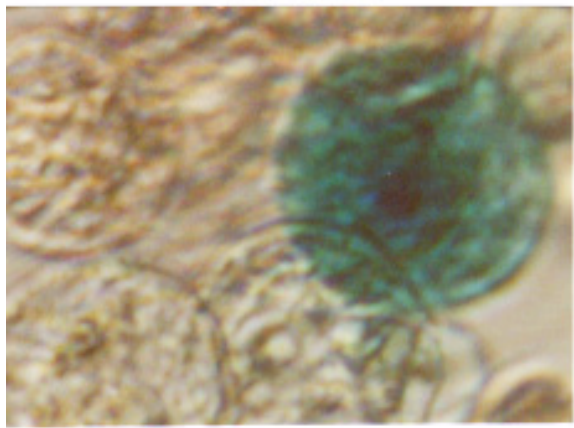

W.T. NLS

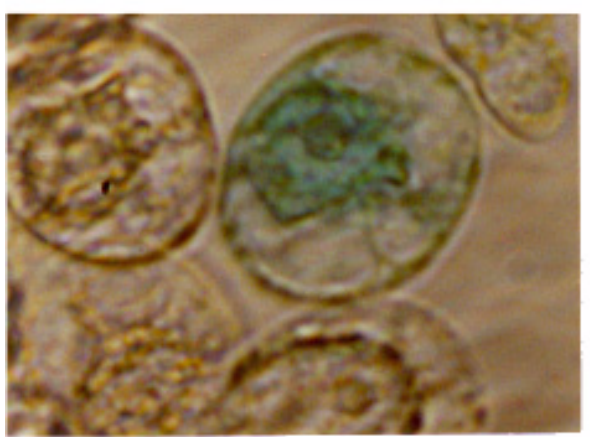

MUT. NLS I

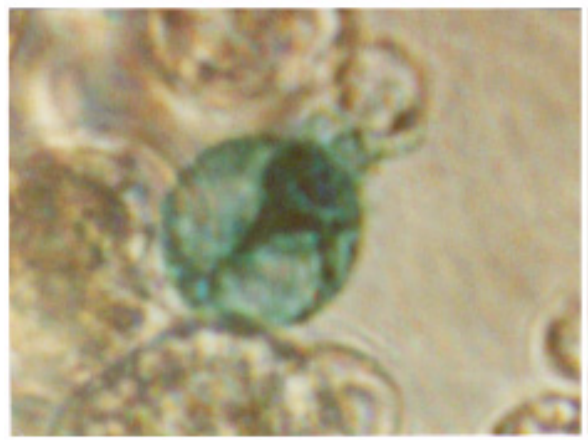

MUT. NLS II

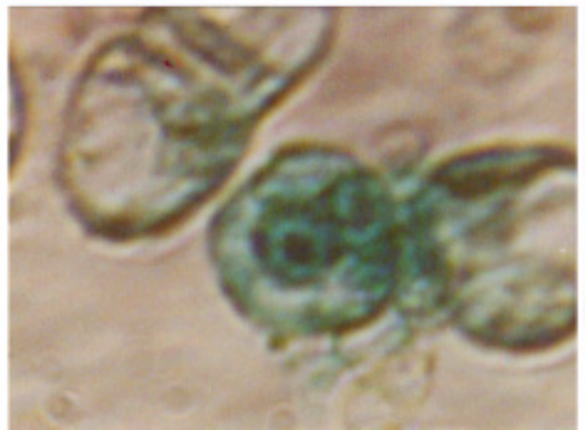

MUT. NLS I+NLS II

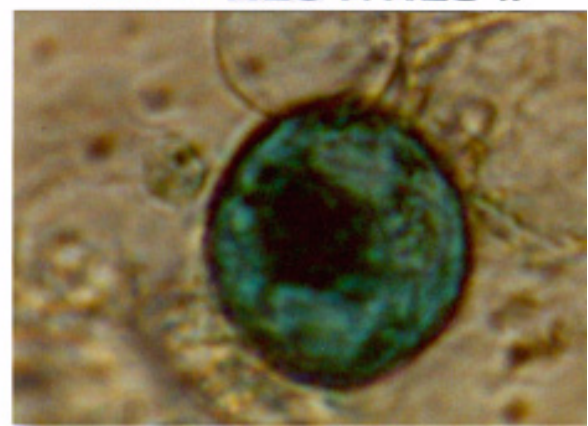

MUT. SPACER

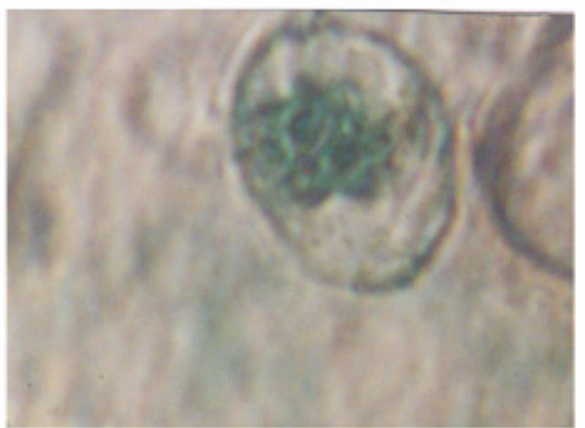

\section{MUT. TOTAL NLS}

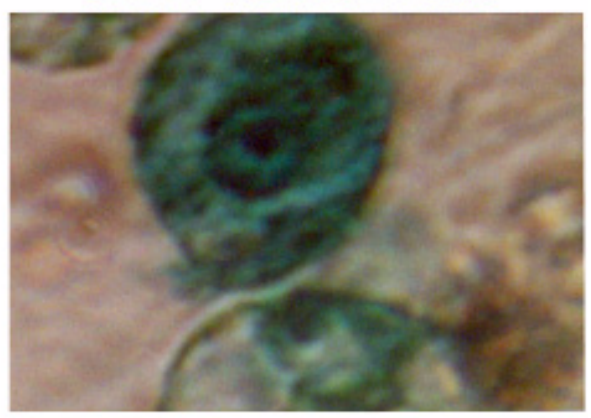

$\Delta \omega$

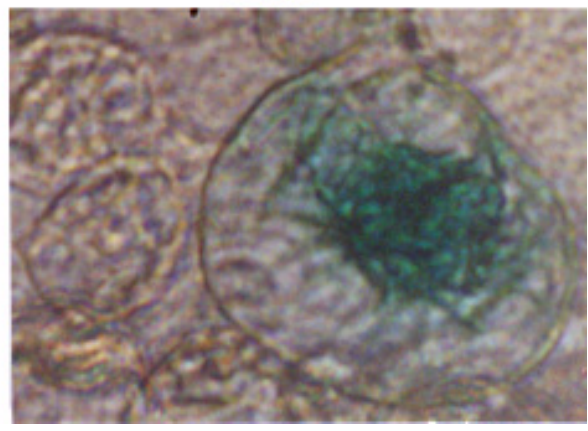

Fig. 10. Cytological localization of $\beta$-glucuronidase (GUS) activity in tobacco protoplasts electroporated with wild-type and mutant gusA-virD2 fusion genes. Tobacco protoplasts were electroporated with gusA plasmids either lacking the VirD2 bipartite nuclear localization sequence (NLS), or containing wild-type or mutant VirD2 NLS and $\omega$ regions. Cells were stained with 5-bromo-4-chloro-3-indolyl $\beta$-D-glucuronic acid (X-gluc) $20 \mathrm{~h}$ after electroporation and visualized with a phase contrast microscope at $\times 400$ magnification. 
deletion of this region inhibits transformation at a very early step. This deletion may alter the structure of VirD2 protein such that it can still nick the T-DNA border but may fail to pass through the VirB channel or the nuclear pore.

An A. tumefaciens strain containing an $\omega$ deletion/substitution mutation exhibits very low virulence compared with that of a strain containing the wild-type virD2 gene (Shurvinton et al. 1992). Our GUS staining data (Table 2) were consistent with these observations. X-gluc staining of tobacco cells infected with this virD2 $\omega$ mutant resulted in only a few blue cell clusters. Although both the virulence and the ability to transform plant cells to express GUS activity stably were very low with this mutant strain, RT-PCR analysis showed relatively high (20\% of wild type) transient levels of gusA mRNA (Fig. 1, Table 1, and Narasimhulu et al. 1996). However, the presence of gusA transcripts in infected tobacco cells was transient (Fig. 1 and Narasimhulu et al. 1996). Thus, the $\omega$ region is not essential for T-DNA transfer or nuclear targeting. Wild-type levels of targeting of a GUS-VirD2 $\Delta \omega$ fusion protein to tobacco nuclei (Fig. 9) corroborate this result. The substitution of two serine residues for four $\omega$ amino acids may alter the conformation of VirD2 protein. The fivefold reduction (Table 1) in the transient level of gusA transcripts in tobacco cells infected by a strain harboring this $\omega$ mutation, compared with the wild-type virD2 gene, is consistent with our suggestion that the conformation of VirD2 may additionally be important for T-DNA transfer and/or nuclear targeting. However, the extremely low virulence of this particular virD2 $\omega$ mutation may be explained by the probable involvement of the VirD2 $\omega$ domain in T-DNA integration. We took two approaches to test this hypothesis.

\section{The $\omega$ region of VirD2 is involved in T-DNA integration.}

When tobacco cells were infected with an A. tumefaciens strain that contained the virD2 $\omega$ deletion/substitution mutation, gusA transcripts initially accumulated with almost the same kinetics as when the plant cells were infected with a wild-type strain harboring pBISN2 (Fig. 1 and Narasimhulu et al. 1996). However, the level of gusA mRNA detected $36 \mathrm{~h}$ after infection with the $\omega$ mutant strain was only $20 \%$ of that seen when the wild-type strain was used (Table 1 and Narasimhulu et al. 1996). Similarly, the number of tobacco cell clusters stained blue 5 days after infection with an $\omega \mathrm{mu}-$ tant virD2 strain was approximately $20 \%$ of that with the wild-type virD2 strain (Fig. 2). The percentage of cell clusters stained blue with X-gluc is lower in Table 2 than in Figure 2 because the infection protocol differed between these two experiments. To obtain the data shown in Figure 2, we cocultivated the bacteria and tobacco cells $48 \mathrm{~h}$ before killing the bacteria with antibiotics, whereas we cocultivated the bacteria and plant cells for only $12 \mathrm{~h}$ to obtain the data for Table 2 . Cocultivation for longer times increased the percentage of infected tobacco cells, allowing us to quantitate better the effect of the $\omega$ mutation on transformation. The transient expression of GUS activity and gusA mRNA with the $\omega$ mutant strain was relatively high compared with the virulence of this strain (Shurvinton et al. 1992). However, the $\omega$ virD2 mutant strain was much less efficient than the wild-type strain in stabilizing GUS activity after 8 days of infection.

Our first approach to test the hypothesis that the $\omega$ region of VirD2 is involved in T-DNA integration used a "promoter trap" vector in which we transformed a promoterless gusA gene (Fig. 3) into tobacco cells. The rationale for this experiment was that GUS expression would occur only after integration of the T-DNA downstream of a plant promoter. "Promoter trap" vectors have been used by a number of scientists to investigate both plant gene expression and the integration preferences of T-DNA (Koncz et al. 1989; Ott and Chua 1990; Goldsbrough and Bevan 1991; Fobert et al. 1994). Table 3 shows that 0.3 to $0.4 \%$ of the cocultivated tobacco cells stained blue with X-gluc when the T-DNA from the vector pKM1 was delivered from wild-type A. tumefaciens cells. However, we could not detect GUS activity when this T-DNA was transferred from a virD2 $\omega$ mutant strain. To show that the "promoter trap" T-DNA could be transferred to tobacco nuclei, we determined that transcription of a luc gene under the control of a CaMV 35S promoter occurred when delivered from within the same T-DNA as the promoterless gusA-intron gene in the $\omega$ mutant strain (Fig. 4). We could not directly visualize the RT-PCR amplification product of the luc gene from the cells infected with the A. tumefaciens strain containing either wild-type or an $\omega$ mutant VirD2. It was therefore necessary for us to detect transcription of the luc gene by hybridization. The likely reason for this result was that the transcription of the luc gene was driven by a CaMV $35 \mathrm{~S}$ promoter, while our previous RT-PCR experiments involved amplification of a gusA-intron gene driven by a "superpromoter" that is approximately 100 times stronger than the CaMV 35S promoter (Ni et al. 1995). These results further suggested that the $\omega$ region of $\operatorname{VirD} 2$ was primarily involved in T-DNA integration, but not greatly involved in T-DNA transfer and nuclear targeting. Interestingly, two other virD2 mutant alleles resulted in a similarly weak decrease in T-DNA transfer efficiency, but had no influence on the efficiency or precision of T-DNA integration (Bravo-Angel et al. 1998).

We therefore directly tested the integration of T-DNA into high-molecular-weight plant DNA after infection of A. thaliana suspension cells with $A$. tumefaciens strains harboring wild-type or $\omega$ mutant virD2 alleles. The genome size of $A$. thaliana is approximately $3 \%$ that of tobacco (Arumuganathan and Earle 1991). Thus, it was easier to detect the integration of T-DNA into the genome of $A$. thaliana than into that of tobacco. Figure 5 shows that T-DNA integrated into A. thaliana high-molecular weight DNA to a much greater extent when the plant cells were infected with an A. tumefaciens strain harboring a wild-type virD2 gene than with a strain containing a $\omega$ mutant virD2 gene. These data directly demonstrate that the $\omega$ domain of VirD2 protein is involved in TDNA integration.

\section{A virD2 $\omega$ mutant cleaves and integrates T-DNA precisely.}

Tinland et al. (1995) showed that changing arginine residue 129 of VirD2 to a glycine (R129G) resulted in the alteration of a number of properties of the protein. Although this mutant VirD2 could efficiently nick a T-DNA border and bind to the $5^{\prime}$ end of the T-strand with the same precision as the wild-type protein in vitro, the mutant protein processed T-DNA inefficiently in A. tumefaciens. Hence, the T-DNA transfer efficiency to tobacco cells, as determined by GUS expression, was greatly reduced. By measuring the frequency of transformation of tobacco to kanamycin-resistance, Tinland et al. (1995) calculated that the T-DNA integration frequency (the 
ratio of transformation efficiency to transfer efficiency) was not altered with the mutant virD2 strain. However, use of the R129G virD2 gene altered the precision with which T-DNA at the right border nick site was ligated to plant DNA. These authors therefore concluded that VirD2 played a role in TDNA integration into the plant genome.

Because the VirD2 $\omega$ deletion/substitution mutation described above altered the efficiency of T-DNA integration, we investigated whether this mutant VirD2 protein cleaved a TDNA border precisely in vitro, and whether the in vivo precision of use of the right T-DNA border to join T-DNA to tobacco DNA was normal. Our results (Fig. 7) showed that the $\omega$ mutant VirD2 cleaved a right border efficiently and correctly in vitro. To determine the pattern of T-DNA integration in those few tobacco tumors that we obtained with the virD2 $\omega$ mutant, we amplified from tumor DNA the T-DNA right border region (Tinland and Hohn 1993; Koncz et al. 1994) with different primer combinations (Fig. 6A). Our results showed that in all tumors tested, whether they were incited by A. tumefaciens strains harboring a wild-type or $\omega$ mutant virD2 gene, we could amplify a segment of T-DNA whose junction with plant DNA was located very close to the $5^{\prime}$ VirD2 nick site. From these results we conclude that, although the VirD2 $\omega$ mutation affected the efficiency of T-DNA integration, it did not affect the precision of use of the right border during integration. Thus, the $\omega$ mutation that we investigated had the opposite effect of the R129G mutation: This mutation of $\omega$ resulted in a low frequency of T-DNA integration, but those few integration events joined T-DNA with plant DNA at or very near the right border nick site. However, the R129G mutation resulted in a relatively high frequency of imprecise T-DNA integration.

\section{The $\omega$ region of virD2 does not have nuclear targeting activity.}

The C-terminal region of VirD2 contains an NLS that can target both T-DNA and fusion proteins to plant nuclei (Howard et al. 1992; Shurvinton et al. 1992; Tinland et al. 1992; Koukolikova-Nicola et al. 1993; Rossi et al. 1993). To determine the relative contribution to nuclear targeting of various peptide domains in the NLS and $\omega$ regions of VirD2, we constructed chimeric genes in which various mutant VirD2 peptides were fused to the $\mathrm{C}$ terminus of GUS protein (Fig. 8). We took care to preserve the basic charge of the mutagenized domains. Electroporation of these genes into tobacco protoplasts, followed by staining with X-gluc, revealed the targeting activity of each mutant protein (Figs. 9 and 10). Our results indicated that mutagenesis of either one of the two bipartite NLS motifs resulted in only a slight decrease in nuclear targeting activity. These results are similar to those obtained by Howard et al. (1992) and Shurvinton et al. (1992). Mutation of both bipartite NLS motifs resulted in a further reduction, but not elimination, of nuclear targeting activity. Shurvinton et al. (1992) showed that deletion of both NLS motifs severely attenuated virulence of the resulting A. tumefaciens strain when inoculated on tobacco. However, infection of potato disks with this VirD2 NLS mutant only reduced virulence by approximately $40 \%$. Thus, the importance of the VirD2 NLS to virulence may depend upon the species of host plant. In order to eliminate nuclear targeting activity, we had to mutate a larger, 20 amino acid domain containing both NLS motifs and the intervening "spacer" amino acids. Mutation of only the spacer region between the two components of the bipartite NLS did not affect nuclear targeting of the fusion protein.

The $\omega$ domain adjoins the C-terminal NLS of VirD2, and because of this close proximity to the NLS, all GUS-VirD2 NLS fusions tested to date have included the $\omega$ domain (Howard et al. 1992; Tinland et al. 1992; Rossi et al. 1993). Thus, the possible role of $\omega$ in nuclear targeting was not tested previously. It was especially important to test for such a role in light of our observation that elimination of the $\omega$ domain reduced transient expression of a gusA gene transferred to tobacco. Elimination of $\omega$ from the GUS-VirD2 fusion protein did not reduce nuclear localization of this protein. Thus, the $\omega$ domain of VirD2 is not essential for targeting the fusion protein to plant nuclei.

The results of this study indicate that the $\omega$ domain of VirD2 is involved in T-DNA integration. Although we do not currently understand the precise role that $\omega$ plays in this process, we hypothesize that this domain of VirD2, a part of the Tcomplex, may either be involved in establishing the correct conformation of the protein, or may directly interact with plant factor(s) that mediate T-DNA integration into the plant genome. Although we have shown evidence for the role of the $\omega$ domain of VirD2 in T-DNA integration, we cannot rule out other possible functions of the $\omega$ domain. For example, the $\omega$ domain may be important for T-complex transport before nuclear targeting. The $\omega$ domain may also play a role in stabilizing the T-complex in the nucleus and preparing it for transcription. Understanding the precise role of the $\omega$ domain warrants further investigation.

\section{MATERIALS AND METHODS}

\section{Bacterial strains and growth conditions.}

E. coli strains were grown at $37^{\circ} \mathrm{C}$ on Luria-Bertani medium (Maniatis et al. 1982) and A. tumefaciens strains at $30^{\circ} \mathrm{C}$ on AB-sucrose minimal medium (Lichtenstein and Draper 1986) containing the appropriate antibiotics. Antibiotic concentrations $(\mu \mathrm{g} / \mathrm{ml})$ used were as follows: ampicillin, 100; kanamycin, 40 for E. coli; carbenicillin, 100; kanamycin, 100; spectinomycin, 50; rifampicin, 10 for $A$. tumefaciens. Table 4 lists the $A$. tumefaciens strains used in this study and their relevant characteristics. We conducted recombinant DNA experiments under P1 containment conditions as specified by the National Institutes of Health recombinant DNA guidelines.

\section{Growth of plant cell cultures.}

Tobacco (Nicotiana tabacum) BY-2 cells were propagated in Murashige and Skoog medium (1962; Gibco BRL, Grand Island, NY) containing $3 \%$ sucrose, $1 \mu \mathrm{g}$ of thiamine- $\mathrm{HCl}$ per $\mathrm{ml}, 0.2 \mu \mathrm{g}$ of 2,4-dichlorophenoxy acetic acid (2,4-D) per ml, and $370 \mu \mathrm{g}$ of $\mathrm{KH}_{2} \mathrm{PO}_{4}$ per ml. A. thaliana Aa- 0 cells were propagated in Murashige and Skoog medium containing 3\% sucrose, $1 \mu \mathrm{l}$ of vitamin stock solution per $\mathrm{ml}(0.5 \mathrm{mg}$ of nicotinic acid, $0.5 \mathrm{mg}$ of pyridoxine, and $0.5 \mathrm{mg}$ of thiamine- $\mathrm{HCl}$ per $\mathrm{ml}), 100 \mu \mathrm{g}$ of myo-inositol per $\mathrm{ml}, 0.5 \mathrm{mg}$ of $2-(\mathrm{N}$ morpholino)ethanesulfonic acid (MES) per ml, $0.55 \mu \mathrm{g}$ of 2,4$\mathrm{D}$ per $\mathrm{ml}$, and $0.8 \mu \mathrm{g}$ of kinetin per $\mathrm{ml}$. The $\mathrm{pH}$ of both media was adjusted to 5.7 with $\mathrm{KOH}$. The cultures were shaken at $140 \mathrm{rpm}$ (gyratory water bath shaker, model G76, New Brunswick Scientific, New Brunswick, NJ) at $25^{\circ} \mathrm{C}$. 
Infection of plant cell cultures, determination of GUS activity, isolation of plant RNA, RT-PCR, and quantitation of gusA mRNA.

Infection of plant cell cultures, determination of GUS activity, isolation of plant RNA, RT-PCR, and quantitation of gusA mRNA were performed basically as described in Narasimhulu et al. (1996). We quantitated gusA mRNA by adding a known quantity of in vitro-transcribed gusA-intron RNA to the RT-PCR reaction containing plant RNA. This control RNA was transcribed from pE1288 (Narasimhulu et al. 1996) with T7 RNA polymerase and an in vitro transcription kit (Stratagene, La Jolla, CA) according to the specifications of the supplier. We mixed various amounts of in vitrosynthesized gusA-intron RNA with $1 \mu \mathrm{g}$ of plant RNA and subjected the mixture to RT-PCR as described, including the use of oligo-dT to prime cDNA synthesis. Following electrophoresis of the amplified products, we compared the signal intensity derived from the gusA-intron RNA (732 bp) with that derived from the processed gusA mRNA (543 bp). We quantitated the amount of processed gusA mRNA in the plant samples by comparison with the amount of gusA-intron RNA that yielded a signal of the same intensity.

Slight variations in some of the procedures were as follows: In the experiment examining the stability of GUS activity (Fig. 2) and in the promoter trap experiment (Table 3), 10-fold more bacteria were used to infect tobacco cells than were used by Narasimhulu et al. (1996). In addition, for these two experiments the cocultivation of the bacteria and plant cells was extended to $48 \mathrm{~h}$. After $48 \mathrm{~h}$, the bacteria were killed by adding either $100 \mu \mathrm{g}$ of timentin per $\mathrm{ml}$ or $200 \mu \mathrm{g}$ of cefotaxime per $\mathrm{ml}$. The infected plant cells were subsequently grown for several days in the presence of these antibiotics.

In the case of the promoter trap experiments, we amplified $l u c$ sequences with the primers $5^{\prime}$-CCTCTAGAGGATGGAA CCGC-3' and 5'-CTGGCATGCGAGAATCTGACG-3'. Amplification conditions were as described in Narasimhulu et al. (1996).

\section{DNA extraction from cell cultures and DNA blot hybridization.}

Genomic DNA was extracted from rapidly growing suspension cell cultures. A standard salt precipitation method was used (Dellaporta et al. 1983). Between 1.0 and $2.0 \mathrm{~g}$ of cells was ground to a fine powder in a mortar in the presence of liquid nitrogen. The powdered tissue was transferred to a capped plastic tube containing $7 \mathrm{ml}$ of extraction buffer (50 $\mathrm{mM}$ Tris- $\mathrm{HCl}, \mathrm{pH} 8.0 ; 10 \mathrm{mM} \mathrm{Na} 2$ EDTA; $100 \mathrm{mM} \mathrm{NaCl}$; $1.0 \%$ sodium dodecyl sulfate [SDS], and $10 \mathrm{mM} \beta$-mercaptoethanol). The slurry was gently mixed and, after incubation for at least $5 \mathrm{~min}$ at $65^{\circ} \mathrm{C}, 2.5 \mathrm{ml}$ of ice cold $5 \mathrm{M}$ potassium acetate was added. The solution was mixed, incubated on ice for at least $15 \mathrm{~min}$, and centrifuged at $8,000 \times g$ at $4^{\circ} \mathrm{C}$. The supernatant solution was filtered through Miracloth (Calbiochem, La Jolla, CA) into a tube containing $5 \mathrm{ml}$ of isopropanol. The tubes were gently inverted several times to precipitate the DNA and were subsequently centrifuged at 8,000 $\times g$ to collect the precipitated nucleic acids. The pellet was rinsed with $80 \%$ ethanol, air dried, and dissolved in $500 \mu \mathrm{l}$ of Tris-EDTA (10 mM Tris-HCl, pH 8; $1 \mathrm{mM} \mathrm{Na}_{2}$ EDTA). Nucleic acids were reprecipitated by the addition of $50 \mu \mathrm{l}$ of $3 \mathrm{M}$ sodium acetate and $500 \mu \mathrm{l}$ of isopropanol. Nucleic acids were collected by a brief centrifugation, rinsed with $80 \%$ ethanol, and redissolved in 200 to $300 \mu \mathrm{l}$ of Tris-EDTA. The DNA yield and purity were quantified by fluorometry and spectrophotometry, respectively, and the DNA integrity was evaluated by gel electrophoresis.

Five micrograms of undigested genomic DNA was size fractionated by electrophoresis through a $0.6 \%$ agarose gel. The DNA was denatured, neutralized, and transferred to a nylon membrane (Nytran; Schleicher and Schuell, Keene, NH) according to Southern (1975). The DNA was covalently cross-linked to the membrane by exposure to UV light.

The membrane was incubated for at least $4 \mathrm{~h}$ at $65^{\circ} \mathrm{C}$ in $6 \times$ $\mathrm{SSC}(1 \times \mathrm{SSC}$ is $0.15 \mathrm{M} \mathrm{NaCl}, 0.015 \mathrm{M}$ sodium citrate, $\mathrm{pH}$ 7.0), $0.5 \%$ SDS, $5 \times$ Denhardt's solution $(1 \times$ Denhardt's solution is $0.02 \%$ each of bovine serum albumin, ficoll, and polyvinylpyrrolidone), and $250 \mu \mathrm{g}$ of sheared and denatured herring sperm DNA per ml. A gusA gene or an A. thaliana PAL (phenylalanine-ammonia lyase) gene radiolabeled with ${ }^{32} \mathrm{P}$ dCTP (Multiprime DNA Labelling System; Amersham Life Science, Arlington Heights, IL) was added and incubated with the membrane for at least $24 \mathrm{~h}$ at $65^{\circ} \mathrm{C}$. The membrane was washed 4 times with $0.3 \times \mathrm{SSC}, 1.0 \%$ SDS for at least $1 \mathrm{~h}$ each time at $65^{\circ} \mathrm{C}$, and exposed to a phosphorimager screen (Molecular Dynamics, Sunnyvale, CA) for approximately 24 h. Similar conditions and procedures were used for DNA blot transfer of the RT-PCR product and hybridization with the luc gene.

Table 4. Agrobacterium tumefaciens strains used in this study

\begin{tabular}{|c|c|c|c|}
\hline Strain & Description & Antibiotic resistance $^{a}$ & Reference \\
\hline At746 (WR1826) ${ }^{\mathrm{b}}$ & virD2 $\omega$ substitution in WR1715 & Rif, Cb, Kan & Shurvinton et al. 1992 \\
\hline At747 (WR1753) ${ }^{\mathrm{b}}$ & Wild-type virD1+virD2 in WR $1715^{\mathrm{c}}$ & Rif, $\mathrm{Cb}, \mathrm{Kan}$ & Shurvinton et al. 1992 \\
\hline At749 (WR1749) ${ }^{\mathrm{b}}$ & $\Delta \mathrm{NruI}$ virD2 in WR $1715 \mathrm{c}$ & Rif, Cb, Kan & Shurvinton et al. 1992 \\
\hline At751 (WR1766) ${ }^{\mathrm{b}}$ & $\Delta \mathrm{NLS}$ virD2 in WR1715c & Rif, $\mathrm{Cb}, \mathrm{Kan}$ & Shurvinton et al. 1992 \\
\hline At822 & pBISN2 in At747 & Rif, $\mathrm{Cb}, \mathrm{Kan}, \mathrm{Spc}$ & This study \\
\hline At823 & pBISN2 in At749 & Rif, $\mathrm{Cb}, \mathrm{Kan}, \mathrm{Spc}$ & This study \\
\hline At827 & pBISN2 in At751 & Rif, $\mathrm{Cb}, \mathrm{Kan}, \mathrm{Spc}$ & This study \\
\hline At 829 & pBISN2 in At746 & Rif, $\mathrm{Cb}, \mathrm{Kan}, \mathrm{Spc}$ & This study \\
\hline At894 & pBISN2 in A136 ${ }^{\mathrm{d}}$ & Rif, $\mathrm{Cb}, \mathrm{Kan}, \mathrm{Spc}$ & This study \\
\hline At898 & pKM1 in At746 & Rif, $\mathrm{Cb}, \mathrm{Kan}, \mathrm{Spc}$ & This study \\
\hline At899 & pKM1 in At747 & Rif, $\mathrm{Cb}, \mathrm{Kan}, \mathrm{Spc}$ & This study \\
\hline
\end{tabular}

\footnotetext{
${ }^{a}$ Rif, rifampicin; Kan, kanamycin; Cb, carbencillin; Spc, spectinomycin.

${ }^{\mathrm{b}}$ Numbers within parentheses are Ream laboratory strain numbers.

${ }^{c}$ WR1715 is an octopine-type A. tumefaciens strain harboring a 295 codon deletion in virD2 (Shurvinton et al. 1992).

${ }^{\mathrm{d}} \mathrm{A} 136$ is a C58 strain lacking a tumor-inducing (Ti) plasmid.
} 


\section{Construction of the promoter trap vector.}

The plasmid pTDC1 (Filichkin and Gelvin 1993), containing the left and right T-DNA borders from the $\mathrm{T}_{\mathrm{R}}$ T-DNA of $\mathrm{pTiB}_{6} 806$ and an $\mathrm{XbaI}$ site between the borders, was digested with $X b a \mathrm{I}$ and the overhanging ends filled in with the Klenow fragment of DNA polymerase I and nucleotide triphosphates. We digested the plasmid pCNL65 (Liu et al. 1992) with HindIII and $\mathrm{NcoI}$ to release a promoterless gusA-intron gene plus an octopine synthase polyadenylation signal sequence, and filled in the overhanging ends with the Klenow fragment of DNA polymerase I and nucleotide triphosphates. This promoterless gusA-intron gene was cloned into the $\mathrm{XbaI}$-digested and blunted plasmid pTDC1. This resulting plasmid (pE1323) was digested with BstEII (which cuts after the polyadenylation signal sequence) and $B g l \mathrm{II}$ linkers were ligated to this site, resulting in the plasmid pE1341.

A $l u c$-intron gene, originally contained in the plasmid pCAL56 (obtained from Peter Christie, University of Texas Health Sciences Center, Houston) was digested with BamHI and $B g l I I$ to release the $l u c$-intron gene with a CaMV $35 \mathrm{~S}$ promoter and a nopaline synthase polyadenylation signal sequence. This fragment was cloned into the $B g l \mathrm{II}$ site of $\mathrm{pE} 1341$, resulting in the plasmid $\mathrm{pE} 1349$. This plasmid was digested to completion with SmaI and partially with Pst I to release the newly constructed T-DNA region. The SmaI-PstI fragment was cloned into the plasmid pUCD2 (Close et al. 1984) that was previously digested with EcoRV and PstI, resulting in pKM1. pKM1 was mobilized into the appropriate $A$. tumefaciens strains by triparental mating (Ditta et al. 1980).

\section{Tumor DNA extraction.}

Plant tumor DNA was extracted by grinding 7 to $8 \mathrm{~g}$ of tumor tissue in the presence of liquid nitrogen and isolation buffer $(100 \mathrm{mM} \mathrm{NaCl}, 50 \mathrm{mM}$ Tris- $\mathrm{HCl}, \mathrm{pH} 8.0,10 \mathrm{mM}$ $\mathrm{Na}_{2}$ EDTA, and $1.0 \%$ SDS) in a mortar. The extract was centrifuged for $10 \mathrm{~min}$ at $9,000 \mathrm{rpm}$ (Sorvall RC-5B refrigerated superspeed centrifuge, E. I. Du Pont de Nemours, Wilmington, DE) at $4^{\circ} \mathrm{C}$. The supernatant solution was extracted twice with phenol/chloroform (1:1). DNA was precipitated from the supernatant fluid by adding $1 / 10$ vol of 3 $\mathrm{M}$ sodium acetate and $2.5 \mathrm{vol}$ of ethanol. The DNA was wound on a sterile glass rod, air dried, and dissolved in sterile $\mathrm{H}_{2} 0$. This DNA solution was treated with RNAse $(100 \mu \mathrm{g} / \mathrm{ml})$ at $37^{\circ} \mathrm{C}$ for $20 \mathrm{~min}$, and purified by passing through a QIAGEN 500 column (Qiagen, Chatsworth, CA). The DNA yield and purity were quantitated by fluorometry and spectrophotometry, respectively, and the DNA integrity was evaluated by agarose gel electrophoresis.

\section{PCR for detection of T-DNA genes in transgenic tobacco calli.}

The PCR reaction was performed in a total volume of 25 $\mu \mathrm{l}$. The mixture contained $50 \mathrm{ng}$ of plant tumor DNA, 1× PCR reaction buffer (Promega, Madison, WI), $0.25 \mathrm{mM}$ dNTPs, 25 pmol of each of the appropriate primers, and $1 \mathrm{U}$ of Taq DNA polymerase (Promega). The reaction was performed in a PTC-150 minicycler (MJ Research, Watertown, MA) as follows. For the picA primers (Yusibov et al. 1994), the amplification was conducted with the following program: $94^{\circ} \mathrm{C}$ for $3 \mathrm{~min}, 56^{\circ} \mathrm{C}$ for $5 \mathrm{~min}$, and $72^{\circ} \mathrm{C}$ for $2 \mathrm{~min}$, as a first cycle; $94^{\circ} \mathrm{C}$ for $20 \mathrm{~s}, 56^{\circ} \mathrm{C}$ for $1.5 \mathrm{~min}$, and $72^{\circ} \mathrm{C}$ for $2 \mathrm{~min}$, for 35 cycles; $94^{\circ} \mathrm{C}$ for $1 \mathrm{~min}, 56^{\circ} \mathrm{C}$ for $3 \mathrm{~min}$, and $72^{\circ} \mathrm{C}$ for $5 \mathrm{~min}$ in the final cycle. For the tms primers (Yusibov et al. 1994) and rb (right border) primers, the amplification was conducted with the following program: $94^{\circ} \mathrm{C}$ for $5 \mathrm{~min}, 63^{\circ} \mathrm{C}$ for $2 \mathrm{~min}$, and $72^{\circ} \mathrm{C}$ for $1 \mathrm{~min}$, as a first cycle; $94^{\circ} \mathrm{C}$ for $30 \mathrm{~s}, 63^{\circ} \mathrm{C}$ for $1.5 \mathrm{~min}$, and $72^{\circ} \mathrm{C}$ for $1.5 \mathrm{~min}$, for 30 cycles; $94^{\circ} \mathrm{C}$ for $1 \mathrm{~min}, 56^{\circ} \mathrm{C}$ for $3 \mathrm{~min}$, and $72^{\circ} \mathrm{C}$ for $5 \mathrm{~min}$ in the final cycle. The sequences of the rb primers were designed according to the T-DNA sequence of Barker et al. (1983; nucleotide positions in this sequence are indicated by $[\#])$ :

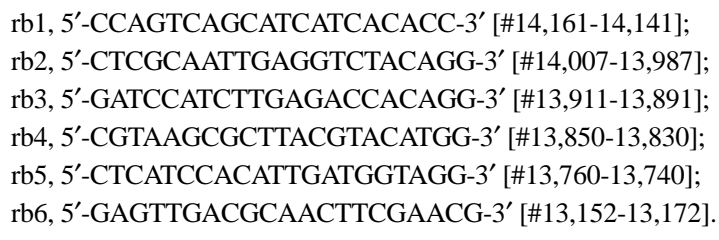

The amplified DNA products from the picA primers were analyzed on a $1 \%$ agarose gel, whereas the amplified products from the tms and the rb primers were analyzed on $1.2 \%$ agarose gels.

\section{In vitro cleavage of right border of T-DNA by VirD2.}

The wild-type VirD2 and the $\omega$ deletion mutant VirD2 (lacking the C-terminal six amino acids) were cloned into the plasmid pET23a (Novagen, Madison, WI). To make these constructions, a NdeI site (including the translation start codon ATG) was affixed to the $5^{\prime}$ end of the virD2 gene with the PCR, and the resulting 379-bp NdeI-SalI fragment of virD2 (encoding the N-terminal portion of VirD2 protein) was cloned into the NdeI and SalI sites of pET23a. The wild-type virD2 gene was reconstituted by linking a 1,110-bp SalI fragment encoding the $\mathrm{C}$-terminal portion of VirD2 protein to the construction described above. The $\omega$-deletion virD2 gene was constructed by replacement of the wild-type C-terminal SalI fragment with a SalI fragment, generated with the PCR, that deleted the C-terminal six amino acids from VirD2. All constructions were confirmed by DNA sequence analysis. VirD2 protein was expressed in E. coli, and purified as described by Jasper et al. (1994). A 498-bp RsaI fragment containing the octopine-type $\mathrm{T}_{\mathrm{R}}$ right border sequence (nucleotides 23,715 to 24,213; Barker et al. 1983) was cloned into the HincII site of pUC118 and used as a target site for the VirD2 endonuclease. This plasmid was first digested with EcoRI prior to the preparation of a uniformly labeled, single-stranded DNA fragment containing the T-DNA border by one-directional PCR with the primer 5'-CCCAGTCACGACGTTGTAAAACGACGGCCA GTGCC- $3^{\prime}$ in the presence of $[\alpha]^{32} \mathrm{P}-\mathrm{dCTP}$. The PCR was carried out for 6 cycles with the following program: $94^{\circ} \mathrm{C}, 5 \mathrm{~min}$; $56^{\circ} \mathrm{C}, 5 \mathrm{~min} ; 72^{\circ} \mathrm{C}, 10 \mathrm{~min}$. In vitro cleavage of the resulting labeled, single-stranded DNA was performed as described (Pansegrau et al. 1993). The labeled, single-stranded DNA fragment was incubated with purified wild-type VirD2 or the $\omega$ mutant VirD2 at $37^{\circ} \mathrm{C}$ in $20 \mu \mathrm{l}$ of reaction buffer $(20 \mathrm{mM}$ Tris- $\mathrm{HCl}, \mathrm{pH} 8.5,5 \mathrm{mM} \mathrm{MgCl} 2,50 \mathrm{mM} \mathrm{NaCl}$ ) for $30 \mathrm{~min}$. The reaction products were separated by electrophoresis through $4 \%$ polyacrylamide gels containing $8 \mathrm{M}$ urea in TBE (Tris-borate-EDTA) buffer (Maniatis et al. 1982). The gels were vacuum dried and exposed to X-ray film. 
Construction of gusA-virD2 gene fusion plasmids.

A 770-bp KpnI-EcoRI fragment from the virD2 gene of the octopine-type Ti plasmid pTiA6 contains the C-terminal 37 amino acids, including the bipartite NLS and the $\omega$ regions. This fragment was cloned into the KpnI and EcoRI sites of pUC19, generating the plasmid pE1299. The plasmid pRTL2GUS/NIa (Restrepo et al. 1990), containing a CaMV 35S promoter, the tobacco etch virus (TEV) leader, a gusA gene, the TEV NIa NLS region, and a CaMV 35S polyA signal sequence, was digested with $X b a \mathrm{I}$. The $X b a \mathrm{I}$ site was made blunt with the Klenow fragment of DNA polymerase I and dNTPs. The resulting plasmid was digested with BglII, deleting the TEV NIa NLS region. Into this linearized molecule was cloned a BamHI-HincII fragment of pE1299. The resulting plasmid, pE1300, contains an in-frame gusA-virD2 NLS fusion gene under the transcriptional control of the CaMV $35 \mathrm{~S}$ promoter. To mutagenize the virD2 region, we cloned a Pst $\mathrm{I}$ fragment from $\mathrm{pE} 1300$, containing the virD2 region, into the PstI site of pBluescript $\mathrm{KS}^{-}$, generating the plasmid pE1303 (GUS-VirD2-NLS). An SmaI fragment from pE1303 was cloned into the SmaI site of pBluescript $\mathrm{KS}^{-}$. Oligonucleotidedirected mutagenesis of virD2 was performed on this SmaI fragment as described by Kunkel et al. (1987), with the following primers:

\section{mut.NLS1, 5'-CAACCGGAAGCTT CTTGGAAGTTTAAAAAGGACCG TCACGATGGA-3'; \\ mut.NLS2, 5'-GATGGAGAATTGGGTTGGAAGAAATTTAAAAAGGG TAATCGTCGCGAC-3'; \\ mut.spacer, 5'-CCGCGTGACCGTCACAACTGGCAGCTGGGTGGACG CAAACG-3'; \\ $\Delta \omega, 5^{\prime}$-GGTAATCGTCGCGACACCTAGATCTAGGAAGGACCGAATA- $3^{\prime}$; \\ mut.total NLS, 5'-CAACCGGAAGCTTATGCAGAGCGTCTGCATGTCC GTCTCCGTTTTAAAGAGAGGGTACGCGAACGTACAAGAGG-3'.}

To generate mut.NLS $1+2$, we used the mut.NLS2 oligonucleotide to mutagenize further a derivative of pE1303 that contained the mut.NLS1 mutation. The mutant SmaI fragments were cloned back into pE1303, replacing the wild-type sequence. The sequences of the mutant gusA-virD2 fusion genes were confirmed at the Purdue University DNA sequencing center.

\section{Protoplast preparation, electroporation, and histochemical GUS assay.}

Tobacco BY-2 suspension cells were harvested by centrifugation $(50 \mathrm{ml}, 5 \mathrm{~min}$ at 1,000 rpm [Sorvall GLC-2 centrifuge, DuPont Instruments, Newtown, CT]) and resuspended in an equal volume of protoplast isolation solution $(0.25 \mathrm{M}$ mannitol, $12 \mathrm{mM}$ sodium acetate, and $66 \mathrm{mM} \mathrm{CaCl}_{2}, \mathrm{pH}$ 5.7) containing $1.0 \%$ cellulase R10 (Onozuka, Tokyo), $0.5 \%$ hemicellulase (Sigma, St. Louis, MO), and 0.1\% Y-23 pectolyase (Seishin, Tokyo). The cells were incubated for $4 \mathrm{~h}$ at room temperature with gentle shaking (40 rpm [Orbit EnvironShaker, Lab-Line Instruments, Melrose Park, IL]). Protoplasts were washed twice with protoplast isolation solution and purified by centrifugation ( $900 \mathrm{rpm}, 5 \mathrm{~min}$ [Sorvall GLC-2 centrifuge, DuPont Instruments, Newtown, CT]) through floating solution (0.3 M sucrose, $4.3 \mathrm{~g}$ of Murashige and Skoog salts per liter, $1 \mathrm{mg}$ of thiamine per liter, $370 \mathrm{mg}$ of $\mathrm{KH}_{2} \mathrm{PO}_{4}$ per liter, $99 \mathrm{mg}$ of myo-inositol per liter, $2.88 \mathrm{~g}$ of L-proline per liter, $100 \mathrm{mg}$ of enzymatic casein hydrolysate per liter, 97.6 $\mathrm{mg}$ of MES [2-( $N$-morpholino)ethanesulfonic acid] per liter, $\mathrm{pH}$ 5.7). Protoplasts formed a band at the top of the gradient and were removed and washed with electroporation solution (10 mM HEPES [ $N$-2-hydroxyethylpiperazine- $N$ '-2-ethanesulfonic acid], pH 7.2, $10 \mathrm{mM} \mathrm{NaCl}, 4 \mathrm{mM} \mathrm{CaCl}_{2}, 120 \mathrm{mM}$ $\mathrm{KCl}$, and $0.2 \mathrm{M}$ mannitol). The protoplast concentration was counted in a hemacytometer and adjusted to $3 \times 10^{6}$ protoplasts per ml. Protoplasts were heated for $5 \mathrm{~min}$ at $42^{\circ} \mathrm{C}$, then placed on ice for $10 \mathrm{~min}$. For electroporation, $10^{6}$ protoplasts (300 $\mu \mathrm{l})$ and $50 \mu \mathrm{g}$ of DNA were mixed in electroporation cuvettes and placed on ice for $10 \mathrm{~min}$. The protoplasts were electroporated for $30 \mathrm{~ms}$ at $130 \mathrm{~V}$ with a Gene Pulser electroporation apparatus (BioRad, Hercules, CA). The protoplasts were left on ice for $10 \mathrm{~min}$ after electroporation, then diluted to $3.5 \times 10^{5}$ protoplasts per $\mathrm{ml}$ in $3.5 \mathrm{ml}$ of suspension medium (BY-2 cell propagation media containing $0.4 \mathrm{M}$ mannitol) and incubated for $20 \mathrm{~h}$ at $24^{\circ} \mathrm{C}$.

Cells were assayed for GUS activity as described previously (Jefferson 1987; Gallie et al. 1988). Two hundred and fifty microliters of protoplasts was combined with $2 \mathrm{ml}$ of GUS assay solution containing $2 \mathrm{mM} \mathrm{X}$-gluc and the assay was performed as described by Howard et al. (1992). Blue color usually began to appear after $20 \mathrm{~min}$ of incubation. Protoplasts were observed and photographed after $2 \mathrm{~h}$ with a Diaphot-TMD inverted phase contrast microscope (Nikon, Tokyo). Each experiment was conducted a minimum of four times.

\section{ACKNOWLEDGMENTS}

We thank Peter Christie (University of Texas Health Sciences Center, Houston) for kindly providing to us the luciferase-intron gene, James Carrington (Texas A\&M University) for providing pRTL2-GUS/NIa, Larry Hodges and Marc Curtis for performing the oligonucleotidedirected mutagenesis experiments, Bill Weissinger for his help with tumor DNA extraction, Jaesung Nam for providing A. thaliana Aa-0 suspension cell cultures, Barbara Hohn and members of her laboratory for many interesting discussions, and Lan-Ying Lee for critical reading of the manuscript. This work was supported by a grant from the US Department of Agriculture (no. 95-37301-2040).

\section{LITERATURE CITED}

Akiyoshi, D. E., Morris, R. O., Hinz, R., Mischke, B. S., Kosuge, T., Garfinkel, D. J., Gordon, M. P., and Nester, E. W. 1983. Cytokinin/auxin balance in crown gall tumors is regulated by specific loci in the T-DNA. Proc. Natl. Acad. Sci. USA 80:407-411.

Albright, L. M., Yanofsky, M. F., Leroux, B., Ma, D., and Nester, E. W. 1987. Processing of the T-DNA of Agrobacterium tumefaciens generates border nicks and linear, single-stranded T-DNA. J. Bacteriol. 169: 1046-1055.

Arumuganathan, K., and Earle, E. D. 1991. Nuclear DNA content of some important plant species. Plant Mol. Biol. Rep. 9:208-218.

Barker, R. F., Idler, K. B., Thompson, D. V., and Kemp, J. D. 1983. Nucleotide sequence of the T-DNA region from the Agrobacterium tumefaciens octopine Ti-plasmid pTi15955. Plant Mol. Biol. 2:335-350.

Binns, A. N., Beaupre, C. E., and Dale, E. M. 1995. Inhibition of VirBmediated transfer of diverse substrates from Agrobacterium tumefaciens by the IncQ plasmid RSF1010. J. Bacteriol. 177:4890-4899.

Bravo-Angel, A. M., Hohn, B., and Tinland, B. 1998. The omega sequence of VirD2 is important but not essential for efficient transfer of T-DNA by Agrobacterium tumefaciens. Mol. Plant-Microbe Interact. 11:57-63.

Chilton, M.-D., Drummond, M. H., Merlo, D. J., Sciaky, D., Montoya, A. L., Gordon, M. P., and Nester, E. W. 1977. Stable incorporation of 
plasmid DNA into higher plant cells: The molecular basis of crown gall tumorigenesis. Cell 11:263-271.

Christie, P. J., Ward, J. E., Gordon, M. P., and Nester, E. W. 1989. A gene required for transfer of T-DNA to plants encodes an ATPase with autophosphorylating activity. Proc. Natl. Acad. Sci. USA 86:96779681.

Christie, P. J., Ward, J. E., Winans, S. C., and Nester, E. W. 1988. The Agrobacterium tumefaciens virE2 gene product is a single-strandedDNA-binding protein that associates with T-DNA. J. Bacteriol. 170: 2659-2667.

Citovsky, V., De Vos, G., and Zambryski, P. 1988. Single-stranded DNA binding protein encoded by the virE locus of Agrobacterium tumefaciens. Science 240:501-504.

Citovsky, V., Warnick, D., and Zambryski, P. 1994. Nuclear import of Agrobacterium VirD2 and VirE2 proteins in maize and tobacco. Proc. Natl. Acad. Sci. USA 91:3210-3214.

Citovsky, V., Zupan, J., Warnick, D., and Zambryski, P. 1992. Nuclear localization of Agrobacterium VirE2 protein in plant cells. Science 256:1802-1805.

Close, T. J., Zaitlin, D., and Kado, C. I. 1984. Design and development of amplifiable broad-host-range cloning vectors: Analysis of the vir region of Agrobacterium tumefaciens plasmid pTiC58. Plasmid 12: 111-118.

Das, A. 1988. Agrobacterium tumefaciens virE operon encodes a singlestranded DNA-binding protein. Proc. Natl. Acad. Sci. USA 85:29092913.

Dellaporta, S. L., Wood, J., and Hicks, J. B. 1983. A plant DNA minipreparation: Version 2. Plant Mol. Biol. Rep. 1:19-22.

Ditta, G., Stanfield, S., Corbin, D., and Helinski, D. R. 1980. Broad host-range DNA cloning system for Gram-negative bacteria: Construction of a gene bank of Rhizobium meliloti. Proc. Natl. Acad. Sci. USA 77:7347-7351.

Filichkin, S. A., and Gelvin, S. B. 1993. Formation of a putative relaxation intermediate during T-DNA processing directed by the Agrobacterium tumefaciens VirD1, D2 endonuclease. Mol. Microbiol. 8:915926.

Fobert, P. R., Labbe, H., Cosmopoulos, J., Gottlob-McHugh, S., Ouellet, T., Hattori, J., Sunohara, G., Iyer, V. N., and Miki, B. L. 1994. T-DNA tagging of a seed coat-specific cryptic promoter in tobacco. Plant J. 6: 567-577.

Gallie, D. R., Lucas, W. J., and Walbot, V. 1988. Visualizing mRNA expression in plant protoplasts: Factors influencing efficient mRNA uptake and translation. Plant Cell 1:303-311.

Gelvin, S. B. 1992. Chemical signaling between Agrobacterium and its plant host. Pages 137-167 in: Molecular Signals in Plant-Microbe Communications. D. P. S. Verma, ed. CRC Press. Boca Raton, FL.

Gietl, C., Koukolikova-Nicola, Z., and Hohn, B. 1987. Mobilization of T-DNA from Agrobacterium to plant cells involves a protein that binds single-stranded DNA. Proc. Natl. Acad. Sci. USA 84:90069010.

Goldsbrough, A., and Bevan, M. 1991. New patterns of gene activity in plants detected using an Agrobacterium vector. Plant Mol. Biol. 16: 263-269.

Herrera-Estrella, A., Chen, Z.-M., Van Montagu, M., and Wang, K. 1988. VirD proteins of Agrobacterium tumefaciens are required for the formation of a covalent DNA-protein complex at the $5^{\prime}$ terminus of T-strand molecules. EMBO J. 7:4055-4062.

Herrera-Estrella, A., Van Montagu, M., and Wang, K. 1990. A bacterial peptide acting as a plant nuclear targeting signal: The amino-terminal portion of Agrobacterium VirD2 protein directs a $\beta$-galactosidase fusion protein into tobacco nuclei. Proc. Natl. Acad. Sci. USA 87:95349537.

Hooykaas, P. J. J., and Beijersbergen, A. G. M. 1994. The virulence system of Agrobacterium tumefaciens. Annu. Rev. Phytopathol. 32: 157-179.

Howard, E., and Citovsky, V. 1990. The emerging structure of the Agrobacterium T-DNA transfer complex. BioEssays 12:103-108.

Howard, E. A., Winsor, B. A., De Vos, G., and Zambryski, P. 1989. Activation of the T-DNA transfer process in Agrobacterium results in the generation of a T-strand-protein complex: Tight association of VirD2 with the $5^{\prime}$ ends of T-strands. Proc. Natl. Acad. Sci. USA 86:40174021.

Howard, E. A., Zupan, J. R., Citovsky, V., and Zambryski, P. C. 1992. The VirD2 protein of A. tumefaciens contains a C-terminal bipartite nuclear localization signal: Implications for nuclear uptake of DNA in plant cells. Cell 68:109-118.

Jasper, F., Koncz, C., Schell, J., and Steinbiss, H.-H. 1994. Agrobacterium T-strand production in vitro: Sequence-specific cleavage and 5 protection of single-stranded DNA templates by purified VirD2 protein. Proc. Natl. Acad. Sci. USA 91:694-698.

Jayaswal, R. K., Veluthambi, K., Gelvin, S. B., and Slightom, J. L. 1987. Double-stranded cleavage of T-DNA and generation of singlestranded T-DNA molecules in Escherichia coli by a virD-encoded border-specific endonuclease from Agrobacterium tumefaciens. J. Bacteriol. 169:5035-5045.

Jefferson, R. A. 1987. Assaying chimeric genes in plants: The GUS gene fusion system. Plant. Mol. Biol. Rep. 5:387-405.

Jen, G. C., and Chilton, M.-D. 1986. The right border region of pTiT37 T-DNA is intrinsically more active than the left border region in promoting T-DNA transformation. Proc. Natl. Acad. Sci. USA 83:38953899.

Koncz, C., Martini, N., Mayerhofer, R., Koncz-Kalman, Z., Korber, H., Redie, G. P., and Schell, J. 1989. High-frequency T-DNA-mediated gene tagging in plants. Proc. Natl. Acad. Sci. USA 86:8467-8471.

Koncz, C., Nemeth, K., Redei, G. P., and Schell, J. 1994. Homology recognition during T-DNA integration into plant genome. Pages 167189 in: Homologous Recombination and Gene Silencing in Plants. Kluwer Academic, Dordrecht, The Netherlands.

Koukolikova-Nicola, Z., Raineri, D., Stephens, K., Ramos, C., Tinland, B., Nester, E. W., and Hohn, B. 1993. Genetic analysis of the virD operon of Agrobacterium tumefaciens: A search for functions involved in transport of T-DNA into the plant cell nucleus and in T-DNA integration. J. Bacteriol. 175:723-731.

Kunkel, T. A., Roberts, J. D., and Zakour, R. A. 1987. Rapid and efficient site-specific mutagenesis without phenotypic selection. Pages 367-382 in: Methods in Enzymology, Volume 154. R. Wu and L. Grossman, eds. Academic Press, San Diego, CA.

Lichtenstein, C., and Draper, J. 1986. Genetic engineering of plants Pages 67-119 in: DNA cloning. A Practical Approach, Volume 2. D. M. Glover, ed. IRL Press, Oxford.

Liu, C.-N., Li, X.-Q., and Gelvin, S. B. 1992. Multiple copies of virG enhance the transient transformation of celery, carrot, and rice tissues by Agrobacterium tumefaciens. Plant Mol. Biol. 20:1071-1087.

Maniatis, T. A., Fritsch, E. F., and Sambrook, J. 1982. Molecular cloning: A Laboratory Manual. Cold Spring Harbor Laboratory, Cold Spring Harbor, NY.

Montoya, A. L., Chilton, M.-D., Gordon, M. P., Sciaky, D., and Nester, E. W. 1977. Octopine and nopaline metabolism in Agrobacterium tumefaciens and crown gall tumor cells: Role of plasmid genes. J. Bacteriol. 129:101-107.

Murashige, T., and Skoog, F. 1962. A revised medium for rapid growth and bioassays with tobacco tissue cultures. Physiol. Plant. 15:473497.

Narasimhulu, S. B., Deng, X.-B., Sarria, R., and Gelvin, S. B. 1996. Early transcription of Agrobacterium T-DNA genes in tobacco and maize. Plant Cell 8:873-886.

Ni, M., Cui, D., Einstein, J., Narasimhulu, S., Vergara, C. E., and Gelvin, S. B. 1995. Strength and tissue specificity of chimeric promoters derived from the octopine and mannopine synthase genes. Plant J. 7: 661-676.

Ott, R. W., and Chua, N.-H. 1990. Enhancer sequences from Arabidopsis thaliana obtained by library transformation of Nicotiana tabacum. Mol. Gen. Genet. 223:169-179.

Pansegrau, W., Schoumacher, F., Hohn, B., and Lanka, E. 1993. Sitespecific cleavage and joining of single-stranded DNA by VirD2 protein of Agrobacterium tumefaciens Ti plasmids: Analogy to bacterial conjugation. Proc. Natl. Acad. Sci. USA 90:11538-11542.

Peralta, E. G., and Ream, L. W. 1985. T-DNA border sequences required for crown gall tumorigenesis. Proc. Natl. Acad. Sci. USA 82:51125116.

Restrepo, M. A., Freed, D. D., and Carrington, J. C. 1990. Nuclear transport of plant potyviral proteins. Plant Cell 2:987-998.

Robbins, J., Dilworth, S. M., Laskey, R. A., and Dingwall, C. 1991. Two interdependent basic domains in nucleoplasmin nuclear targeting sequence: Identification of a class of bipartite nuclear targeting sequence. Cell 64:615-623.

Rong, L., Karcher, S. J., O'Neal, K., Hawes, M. C., Yerkes, C. D., Jayaswal, R. K., Halliberg, C. A., and Gelvin, S. B. 1990. picA, a novel 
plant-inducible locus on the Agrobacterum tumefaciens chromosome. J. Bacteriol. 172:5828-5836.

Rossi, L., Hohn, B., and Tinland, B. 1993. The VirD2 protein of Agrobacterium tumefaciens carries nuclear localization signals important for transfer of T-DNA to plants. Mol. Gen. Genet. 239:345-353.

Rossi, L., Hohn, B., and Tinland, B. 1996. Integration of complete transferred DNA units is dependent on the activity of virulence E2 protein of Agrobacterium tumefaciens. Proc. Natl. Acad. Sci. USA 93:126130.

Schroder, G., Klipp, W., Hillebrand, A., Ehring, R., Koncz, C., and Schroder, J. 1983. The conserved part of the T-region in Ti-plasmids expresses four proteins in bacteria. EMBO J. 2:403-409.

Sheng, J., and Citovsky, V. 1996. Agrobacterium-plant cell DNA transport: Have virulence proteins, will travel. Plant Cell 8:1699-1710.

Shurvinton, C. E., Hodges, L., and Ream, W. 1992. A nuclear localization signal and the $\mathrm{C}$-terminal omega sequence in the Agrobacterium tumefaciens VirD2 endonuclease are important for tumor formation. Proc. Natl. Acad. Sci. USA 89:11837-11841.

Slightom, J. L., Jouanin, L., Leach, F., Drong, R. F., and Tepfer, D. 1985. Isolation and identification of TL-DNA/plant junctions in Convolvulus arvensis transformed by Agrobacterium rhizogenes strain A4. EMBO J. 4:3069-3077.

Southern, E. M. 1975. Detection of specific sequences among DNA fragments separated by gel electrophoresis. J. Mol. Biol. 98:503-517.

Stachel, S. E., Messens, E., Van Montagu, M., and Zambryski, P. 1985. Identification of the signal molecules produced by wounded plant cells that activate T-DNA transfer in Agrobacterium tumefaciens. Nature 318:624-629.

Stachel, S. E., and Nester, E. W. 1986. The genetic and transcriptional organization of the vir region of the A6 Ti plasmid of Agrobacterium tumefaciens. EMBO J. 5:1445-1454.

Stachel, S. E., Timmerman, B., and Zambryski, P. 1987. Activation of Agrobacterium tumefaciens vir gene expression generates multiple single-stranded T-strand molecules from the pTiA6 T-region: Requirement for 5' virD gene products. EMBO J. 6:857-863.

Steck, T. R., Lin, T.-S., and Kado, C. I. 1990. VirD2 gene product from the nopaline plasmid pTiC58 has at least two activities required for virulence. Nucleic Acids Res. 18:6953-6958.

Sundberg, C., Meek, L., Carroll, K., Das, A., and Ream, W. 1996. VirE1 protein mediates export of the single-stranded DNA-binding protein VirE2 from Agrobacterium tumefaciens into plant cells. J. Bacteriol. 178:1207-1212.

Tinland, B., and Hohn, B. 1993. Plant genome transformation by Agrobacterium tumefaciens is mediated by a nucleoprotein complex. Pages 349-359 in: Virus Strategies. Verlag Chemie, Weinheim, Germany.
Tinland, B., Hohn, B., and Puchta, H. 1994. Agrobacterium tumefaciens transfers single-stranded transferred DNA (T-DNA) into the plant cell nucleus. Proc. Natl. Acad. Sci. USA 91:8000-8004.

Tinland, B., Koukolikova-Nicola, Z., Hall, M. N., and Hohn, B. 1992. The T-DNA-linked VirD2 protein contains two distinct functional nuclear localization signals. Proc. Natl. Acad. Sci. USA 89:7442-7446.

Tinland, B., Schoumacher, F., Gloeckler, V., Bravo Angel, A. M., and Hohn, B. 1995. The Agrobacterium tumefaciens virulence D2 protein is responsible for precise integration of T-DNA into the plant genome. EMBO J. 14:3585-3595.

Vancanneyt, G., Schmidt, R., O'Connor-Sanchez, A., Willmitzer, L., and Rocha-Sosa, M. 1990. Construction of an intron-containing marker gene: Splicing of the intron in transgenic plants and its use in monitoring early events in Agrobacterium-mediated plant transformation. Mol. Gen. Genet. 220:245-250.

Vogel, A. M., and Das, A. 1992. Mutational analysis of Agrobacterium tumefaciens virD2: Tyrosine 29 is essential for endonuclease activity. J. Bacteriol. 174:303-308.

Wang, K., Herrera-Estrella, L., Van Montagu, M., and Zambryski, P. 1984. Right 25 bp terminus sequence of the nopaline T-DNA is essential for and determines direction of DNA transfer from Agrobacterium to the plant genome. Cell 38:455-462.

Wang, K., Stachel, S. E., Timmerman, B., Van Montagu, M., and Zambryski, P. C. 1987. Site-specific nick in the T-DNA border sequence as a result of Agrobacterium vir gene expression. Science 235:587-591.

Ward, E. R., and Barnes, W. M. 1988. VirD2 protein of Agrobacterium tumefaciens very tightly linked to the $5^{\prime}$ end of T-strand DNA. Science 242:927-930.

Yadav, N. S., Van der Leyden, J., Bennett, D. R., Barnes, W. M., and Chilton, M.-D. 1982. Short direct repeats flank the T-DNA on a nopaline Ti plasmid. Proc. Natl. Acad. Sci. USA 79:6322-6326.

Yanofsky, M. F., Porter, S. G., Young, C., Albright, L. M., Gordon, M. P., and Nester, E. W. 1986. The virD operon of Agrobacterium tumefaciens encodes a site-specific endonuclease. Cell 47:471-477.

Young, C., and Nester, E. W. 1988. Association of the VirD2 protein with the $5^{\prime}$ end of T strands in Agrobacterium tumefaciens. J. Bacteriol. 170:3367-3374

Yusibov, V. M., Steck, T. R., Gupta, V., and Gelvin, S. B. 1994. Association of single-stranded transferred DNA from Agrobacterium tumefaciens with tobacco cells. Proc. Natl. Acad. Sci. USA 91:29942998.

Zupan, J. R., and Zambryski, P. 1995. Transfer of T-DNA from Agrobacterium to the plant cell. Plant Physiol. 107:1041-1047.

Zupan, J., and Zambryski, P. 1997. The Agrobacterium DNA transfer complex. Crit. Rev. Plant Sci. 16:279-295. 